\title{
Magnesium in Aging, Health and Diseases
}

\author{
Mario Barbagallo *(1), Nicola Veronese and Ligia J. Dominguez
}

check for updates

Citation: Barbagallo, M.; Veronese, N.; Dominguez, L.J. Magnesium in Aging, Health and Diseases. Nutrients 2021, 13, 463. https://doi.org/10.3390/nu13020463

Academic Editor: Lutz Schomburg Received: 31 December 2020

Accepted: 28 January 2021

Published: 30 January 2021

Publisher's Note: MDPI stays neutra with regard to jurisdictional claims in published maps and institutional affiliations.

Copyright: (c) 2021 by the authors. Licensee MDPI, Basel, Switzerland. This article is an open access article distributed under the terms and conditions of the Creative Commons Attribution (CC BY) license (https:// creativecommons.org/licenses/by/ $4.0 /)$.
Geriatric Unit, Department of Medicine, University of Palermo, 90127 Palermo, Italy; nicola.veronese@unipa.it (N.V.); ligia.dominguez@unipa.it (L.J.D.)

* Correspondence: mario.barbagallo@unipa.it; Tel.: +39-091-655-4828; Fax: +39-091-655-2952

\begin{abstract}
Several changes of magnesium $(\mathrm{Mg})$ metabolism have been reported with aging, including diminished $\mathrm{Mg}$ intake, impaired intestinal $\mathrm{Mg}$ absorption and renal $\mathrm{Mg}$ wasting. Mild $\mathrm{Mg}$ deficits are generally asymptomatic and clinical signs are usually non-specific or absent. Asthenia, sleep disorders, hyperemotionality, and cognitive disorders are common in the elderly with mild $\mathrm{Mg}$ deficit, and may be often confused with age-related symptoms. Chronic Mg deficits increase the production of free radicals which have been implicated in the development of several chronic agerelated disorders. Numerous human diseases have been associated with Mg deficits, including cardiovascular diseases, hypertension and stroke, cardio-metabolic syndrome and type 2 diabetes mellitus, airways constrictive syndromes and asthma, depression, stress-related conditions and psychiatric disorders, Alzheimer's disease (AD) and other dementia syndromes, muscular diseases (muscle pain, chronic fatigue, and fibromyalgia), bone fragility, and cancer. Dietary $\mathrm{Mg}$ and/or $\mathrm{Mg}$ consumed in drinking water (generally more bioavailable than $\mathrm{Mg}$ contained in food) or in alternative $\mathrm{Mg}$ supplements should be taken into consideration in the correction of Mg deficits. Maintaining an optimal $\mathrm{Mg}$ balance all through life may help in the prevention of oxidative stress and chronic conditions associated with aging. This needs to be demonstrated by future studies.
\end{abstract}

Keywords: magnesium; oxidative stress; diseases; dementia; diabetes; osteoporosis; aging; hypertension; health; longevity

\section{Introduction}

Magnesium ion $(\mathrm{Mg})$ is the divalent intracellular cation most present in the human cell and the second cation after potassium (K). Mg atomic weight is $24.305 \mathrm{~g} / \mathrm{mol}$, and its atomic number is 12 (Table 1). Mg has a crucial role in numerous biological processes, including oxidative phosphorylation, energy production, glycolysis, protein and nucleic acid synthesis [1]. Mg plays a role in the mitochondrial synthesis of adenosine triphosphate (ATP) to form MgATP [2]. Cell signaling needs MgATP for protein phosphorylation and activation of cyclic adenosine monophosphate (cAMP), which is involved in a number of biochemical processes [3]. Mg ions participate in the transport of other ions through cell membranes, in muscle contraction, and in controlling neuron excitability. Cellular Mg homeostasis is linked to the cellular metabolism of other ions, i.e., $\mathrm{K}$, sodium $(\mathrm{Na})$, calcium (Ca), via $\mathrm{Na}^{+} / \mathrm{K}^{+} /$ATPase, $\mathrm{Ca}^{++}$activated $\mathrm{K}$ channels, and other mechanisms [4].

Table 1. Characteristics of Ionic Mg.

- $\quad$ Element category: alkaline earth metal

- Atomic number: 12

- $\quad$ Atomic weight: $24.305 \mathrm{~g} / \mathrm{mol}$

- Valence: 2

$\mathrm{Mg}$ has a key role for cellular homeostasis and organ functioning. Thus, $\mathrm{Mg}$ has a physiological role in controlling various key cellular activities and metabolic pathways, 
including enzyme substrate, structural and membrane functions [2,5]. $\mathrm{Mg}$ is a cofactor in over 600 enzymatic reactions and is required for the activity of protein kinases, glycolytic enzymes, for all phosphorylation processes, and for all reactions that implicate ATP [2,5]. $\mathrm{Mg}$ ion has a mild $\mathrm{Ca}$ antagonist action and is involved in a number of structural functions (multi-enzyme complexes, i.e., G-proteins, proteins and nucleic acids synthesis, N-methylD-aspartic acid (NMDA) receptors, mitochondria, polyribosomes, etc.).

In the last decades, the pathophysiological and clinical importance of $\mathrm{Mg}$ has been acknowledged, as well as the possible effects of $\mathrm{Mg}$ deficits on several human diseases.

\section{Mg Metabolism and Requirement}

The $\mathrm{Mg}$ content in the human body is around 24-29 $\mathrm{g}$ of $\mathrm{Mg}$, of which near 2/3 are deposited in bone and 1/3 in the cells. Only $<1 \%$ of the total $\mathrm{Mg}$ is extracellular. $\mathrm{Mg}$ levels in the serum range between 0.75 and $0.95 \mathrm{mmol} / \mathrm{L}$. Serum $\mathrm{Mg}$ levels in healthy subjects are very constant and tightly preserved within this narrow range by a dynamic balance among $\mathrm{Mg}$ intake, its intestinal absorption, kidney excretion, the bone storage and the $\mathrm{Mg}$ requirement of different tissues. $\mathrm{Mg}$ absorption is increased under conditions of $\mathrm{Mg}$ limited assumption. If $\mathrm{Mg}$ deprivation persists, bone storages would help to preserve serum $\mathrm{Mg}$ levels by replacing part of its content in the extracellular compartment [6] (Figure 1). Serum $\mathrm{Mg}$ levels are considered low if inferior than $0.75 \mathrm{mmol} / \mathrm{L}$, while frank hypomagnesemia is generally considered as serum $\mathrm{Mg}$ level lower than $0.7 \mathrm{mmol} / \mathrm{L}[1,2,7]$. Total serum $\mathrm{Mg}$ levels (MgT) are not a sufficiently precise measure of the body $\mathrm{Mg}$ status; $\mathrm{MgT}$ levels are more useful in epidemiological studies, but are not enough accurate to detect subclinical $\mathrm{Mg}$ deficits on a single subject [8]. This is because serum total $\mathrm{Mg}$ levels do not accurately mirror intracellular concentrations, and low intracellular $\mathrm{Mg}$ levels generally precede alterations of serum $\mathrm{Mg}$. It is thus possible to have intracellular and storage $\mathrm{Mg}$ depletion with still normal total serum $\mathrm{Mg}$ values [6].

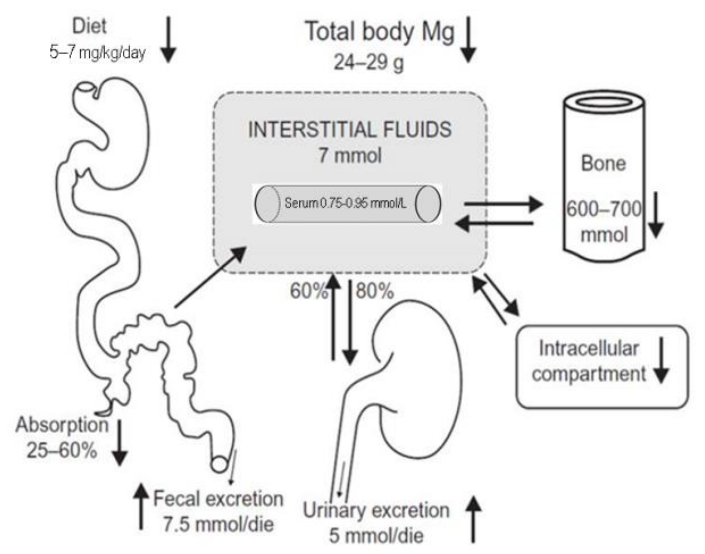

Figure 1. $\mathrm{Mg}$ balance (arrows show most common sites of $\mathrm{Mg}$ depletion with aging), including daily amount of $\mathrm{Mg}$ intake and excretion. Total human body content of $\mathrm{Mg}$ is 24 to $29 \mathrm{~g}$. In order to maintain $\mathrm{Mg}$ balance, a healthy person needs to consume around 5-7 mg/ $\mathrm{kg} /$ day. Daily intestinal absorption varies from 25 to $60 \%$ of $\mathrm{Mg}$ intake. In the kidney, $80 \%$ of circulating $\mathrm{Mg}$ is filtered and about $60 \%$ is reabsorbed along the kidney tubule. This results in a net excretion of about $5 \mathrm{mmol} /$ day. Fecal excretion is about $7.5 \mathrm{mmol} /$ day. The intracellular compartment provides the most important $\mathrm{Mg}$ stores.

Optimal Mg requirement with food is considered to be $320 \mathrm{mg} /$ day for women and $420 \mathrm{mg}$ /day for men, according to the 2015-2020 Dietary Guidelines for Americans [9], but higher requirements may be needed in some physiologic conditions such as pregnancy, aging, or during exercise and in some pathological conditions (i.e., infections, type 2 diabetes mellitus (T2DM), etc.).

Many factors may alter Mg balance: a high content in the diet of $\mathrm{Na}, \mathrm{Ca}$, protein, alcohol or caffeine, or the use of certain drugs (diuretics, e.g., furosemide; proton-pump inhibitors, e.g., 
omeprazole, etc.). Mg absorption mainly occurs in the small intestine [10]. To maintain the balance, a healthy person needs to consume around 5-7 mg/ kg/day (Table 2). $\mathrm{Mg}$ deposited in the bone is not easily exchanged and any rapid $\mathrm{Mg}$ requirement is provided by the $\mathrm{Mg}$ present in the intracellular compartment. The kidney helps to control and modulate $\mathrm{Mg}$ balance; each day around $120 \mathrm{mg}$ of $\mathrm{Mg}$ is eliminated into the urine [1]. Renal $\mathrm{Mg}$ control is strictly dependent on $\mathrm{Mg}$ status, since $\mathrm{Mg}$ depletion stimulates $\mathrm{Mg}$ reabsorption across the nephron, while $\mathrm{Mg}$ urinary excretion is decreased in conditions of body $\mathrm{Mg}$ depletion [11]. Diuretics alter renal $\mathrm{Mg}$ handling increasing $\mathrm{Mg}$ wasting [12]. No hormone is known to be a specific $\mathrm{Mg}$ regulator. However, many hormonal factors have an identified effect on $\mathrm{Mg}$ homeostasis (i.e., insulin, parathyroid hormone (PTH), calcitonin, catecholamines) [6,13].

Table 2. Determining factors of Mg balance.

- Gastrointestinal absorption

- Renal excretion

- Diet Requirements for healthy individuals are $5-7 \mathrm{mg} / \mathrm{kg}$ of body weight/day to stay in balance

- $\quad$ Extracellular $\mathrm{Mg}$ is in equilibrium with $\mathrm{Mg}$ in the storages

- $\quad$ Bone is the main storage site of $\mathrm{Mg}$

- Decreased tubular reabsorption, osmotic diuresis or drugs may cause hypomagnesemia, by Mg wasting

\section{Mg Deficiencies Associated with Reduced Mg Intake}

Several studies have consistently shown that in western countries the average dietary $\mathrm{Mg}$ intakes are often inadequate [14] and significantly lower than the recommended daily intake of $\mathrm{Mg}$ [15]. King et al. in 2005 reported that almost 2/3 of the Americans have a $\mathrm{Mg}$ consumption below the recommended daily allowance (RDA). In forty-five percent of subjects, the daily intake was less than seventy-five percent of the RDA, and in nineteen percent the daily intake was less than fifty percent of the RDA [16]. In Europe, the situation is similar [15]. Even in physically active and well-educated European women, dietary recommendations are not followed [17]. Western diets are generally rich in refined foods that are very poor in $\mathrm{Mg}$ while also having a very low content of whole grains and green vegetables, which are foods rich in $\mathrm{Mg}$ content. Cooking and the refining processes may consistently diminish the $\mathrm{Mg}$ content present in the food since a significant amount of $\mathrm{Mg}$ is lost during these procedures. Thus, diets rich in refined or processed foods are likely to be low in $\mathrm{Mg}$. In particular, the boiling of foods is a major cause of loss of $\mathrm{Mg}$ [18]. The presence of a large quantity of refined and processed food in the western diets may help to explain the large percentage of individuals with a condition of $\mathrm{Mg}$ deficiency [19].

Pathogenic gut microbiota may alter $\mathrm{Mg}$ absorption from the diet. In ruminant, bacteria convert trans-aconitate to tricarballylate, a tricarboxylic acid which chelates blood divalent cations, such as $\mathrm{Mg}$, and decreases their availability. Tricarballylate has been proposed as a factor involved in the hypomagnesemia that leads to grass tetany [20,21].

In addition, phytic acid present in some foods may lower $\mathrm{Mg}$ absorption. Glyphosate, a pesticide frequently used in the crops, may chelate minerals including $\mathrm{Mg}$ [22], further reducing the content of $\mathrm{Mg}$ in the soil and in some crops. Organic food, from pesticidefree soils, was shown to have significantly higher Mg content than non-organic control food [23].

$\mathrm{Mg}$ is widely used in many food products, including a variety of confectionery, spices and baking ingredients, and oral pharmaceutical formulations as anticaking agent, and in preventing contaminations in food and beverages [24].

$\mathrm{Mg}$ consumption from water rich in $\mathrm{Mg}$ may be taken into consideration as an alternative source of $\mathrm{Mg}$ [25]. Drinking water, especially mineral-rich harder water, can be rich in $\mathrm{Mg}$ salts; therefore, water may provide an important supplementary contribution to total $\mathrm{Mg}$ intake, representing a possible alternative to oral supplements, although the $\mathrm{Ca} / \mathrm{Mg}$ ratio in water may play a role. In the SU.VI.MAX cohort, subjects who used to drink water 
rich in $\mathrm{Mg}$ resulted to have significantly higher $\mathrm{Mg}$ intakes than those who used to drink low mineralized or tap water [25].

The bio-availability of $\mathrm{Mg}$ in drinking water is generally higher when compared to $\mathrm{Mg}$ in food and while it is easy to add $\mathrm{Mg}$ to water, it is virtually impossible to add $\mathrm{Mg}$ to foods.

The water content of Mg may be significant not only in the water used for drinking, but also in water used for cooking, since a higher concentration of $\mathrm{Mg}$ in the water used for boiling may reduce the leakage of $\mathrm{Mg}$ in food during cooking, and may reduce the loss of $\mathrm{Mg}$ in the boiled food. With increasing shortage of fresh water globally, the use of desalinated seawater (DSW) is becoming very common in many areas in the world [26]. In Israel, $>50 \%$ of drinking water is now derived from DSW. Desalination removes $\mathrm{Mg}$, and hypomagnesaemia has been associated with increased cardiac morbidity and mortality [27].

\section{Mg Deficits Associated with Aging}

Aging is often associated with a total body $\mathrm{Mg}$ deficit [19]. Serum Mg levels remain constant with age [28]. Alterations in serum Mg are usually associated with the existence of diseases and/or alterations in kidney function. In healthy older persons, an age-dependent decrease in cellular Mg concentration was previously shown [29] in the absence of alterations of total serum $\mathrm{Mg}$. It has been confirmed that chronic latent $\mathrm{Mg}$ deficiency is quite common in older adults in western countries. Possible mechanisms of this demonstrated Mg insufficiency with aging are detailed in Table 3. This Mg shortage is frequently associated with a low Mg intake [30,31], while Mg requirements for the body processes do not change with age [32].

Table 3. Mechanisms of Mg insufficiency in the elderly.

\section{Primary Mg Deficiency:}

- Insufficient Mg dietary intake

- $\quad$ Reduced Mg absorption (often in parallel with reduced vitamin D levels)

- Increased urinary Mg excretion (often related to reduced kidney function and tubular reabsorption, which are common in old age)

\section{Secondary Mg Deficiency:}

- $\quad$ Linked to age-related diseases and comorbidities

- $\quad$ Linked to drug action causing $\mathrm{Mg}$ loss in the urine (i.e., diuretics, proton pump inhibitors)

Data from the National Health and Nutrition Examination (NHANES) III have confirmed that aging is an additional risk factor for inadequate $\mathrm{Mg}$ consumptions and progressive decrease with age [30].

Intestinal absorption of $\mathrm{Mg}$ tends to fall with age, and this decline may be one of the possible causes of $\mathrm{Mg}$ deficit with aging [33]. The alteration of the intestinal absorption of $\mathrm{Mg}$ in old age is often worsened by impairment of vitamin D homeostasis, common in old age. Renal reabsorption of $\mathrm{Mg}$ is an active process occurring in the loop of Henle and in the proximal convoluted tubule. Reduced kidney functionality, common in the elderly, is a possible additional cause of $\mathrm{Mg}$ loss.

Secondary Mg deficiencies in older adults may be linked to the presence of several conditions and related polypharmacotherapy [34]. Diuretic therapy may cause excessive $\mathrm{Mg}$ urinary loss. Diuretic-induced hypomagnesemia is often accompanied by hypokalemia. Hypomagnesemia may be present in around $40 \%$ of patients with hypokalemia, and the correction of $\mathrm{Mg}$ deficit is needed to achieve the correction of the $\mathrm{K}$ deficits. It is thus advisable to evaluate $\mathrm{Mg}$ levels in patients with hypokalemia. Other medications commonly used in the elderly may contribute to Mg deficits (e.g., antacids, $\mathrm{H} 2$ blockers, proton pump inhibitors, antihistamines, antibiotics, antiepileptic drugs, and antivirals, among others). 


\section{5. $\mathrm{Mg}$, Inflammation and Oxidative Stress}

$\mathrm{Mg}$ deprivation, low serum $\mathrm{Mg}$ levels, and reduced dietary Mg intake have all been associated in preclinical, epidemiological and clinical human studies with an increased production of free radicals of oxygen, with low-grade systemic inflammation, increased levels of inflammation markers and proinflammatory molecules (IL-6, tumor necrosis factoralpha (TNF-alfa), IL-1-beta, vascular cell adhesion molecule (VCAM)-1, and plasminogen activator inhibitor (PAI)-1, complement, alfa2-macroblobulin, fibrinogen) [16,35-42].

King et al., using the NHANES database, found that dietary Mg intake was inversely related to reactive protein $C$ levels [16]. Similar results were found by Song et al. using data from the Women's Health Study in adult women [42].

$\mathrm{Mg}$ depletion results in an increased production of oxygen-derived free radicals (ROS) increased oxygen peroxide production, and increased production of superoxide anion by inflammatory cells. Mg deficiency not only increases the oxidative stress but also decreases the antioxidant defense competence [35,43]. $\mathrm{Mg}$ is required for the proper functioning of gamma-glutamyl transpeptidase, which plays a key role in the synthesis of antioxidant glutathione [44], confirming that $\mathrm{Mg}$ may have a mild antioxidant action [45].

In humans, a correlation between intracellular $\mathrm{Mg}$ and circulating reduced/oxidized glutathione ratio has been reported [46]. In another study, a negative correlation between Mg levels and oxidative stress markers (plasma superoxide anions and malondialdehyde) was detected in a population exposed to chronic stress [47].

Aging is accompanied by a low-grade inflammatory state that has been named "inflammaging" [48]. We have previously postulated that a chronic Mg insufficiency facilitating this inflammaging condition and an impairment of the redox status may facilitate the development of age-related illnesses (Figure 2) [19,49]. In particular, we have suggested a link between the $\mathrm{Mg}$ inadequacy and the occurrence of an insulin resistance state, T2DM, and cardiometabolic syndrome [2].

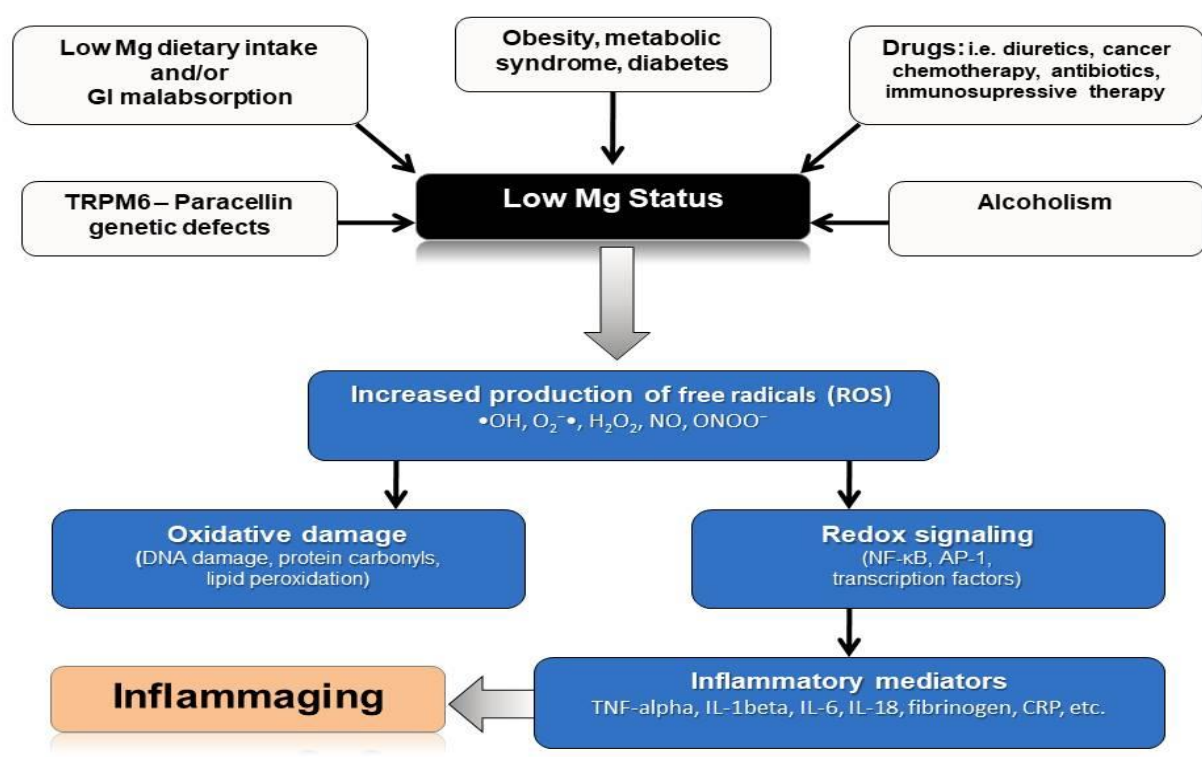

Figure 2. Mg deficit, inflammation, oxidative stress, and aging. The relationship of low $\mathrm{Mg}$ status, generated by multiple factors (i.e., low Mg intake and absorption, $\mathrm{Mg}$ transport genetic defects, obesity, type 2 diabetes mellitus (T2DM) and cardio-metabolic syndrome, polypharmacotherapy, and alcohol abuse), which may trigger an increased production of free radicals (ROS), oxidative damage, and activation of redox signaling (i.e., NF-KB, AP-1, and other transcription factors). The elevation in oxidative stress may lead to the release of inflammatory mediators conforming a state of chronic low-grade inflammation, which has been proposed to accompany aging and called "inflammaging". TRPM7: Transient Receptor Potential cation channel, subfamily M, member 7; ROS: reactive oxygen species; NF-KB nuclear factor kappa-light-chainenhancer of activated B cells; AP-1: activator protein 1; TNF-alpha: tumor necrosis factor-alpha; IL: interleukin; CRP: C-reactive protein. 


\section{Mg and the Immune Responses}

$\mathrm{Mg}$ modulates both innate and acquired immune responses and acts as a mediator in the signaling pathways controlling immune cell development, homeostasis, and activation [35]. Mg is a crucial cofactor for T helper-beta cell adherence, immunoglobulin synthesis, antibody-dependent cytolysis, IgM lymphocyte binding, and macrophage response to lymphokines [37,50]. Mg influences acquired immunity by modulating the proliferation and development of lymphocytes [51]. Transient Receptor Potential cation channel, subfamily M, member 7 (TRPM7) is crucial for Mg homeostasis in immune cells. A fall in free cytosolic Mg and cell cycle arrest was found in TRPM7-deficient B cell lines, which was preserved by culturing the cells in a medium containing high Mg. An impaired development of T cells was observed in TRPM7 knockout mice [52].

$\mathrm{Mg}$ deficiency may accelerate thymus involution. In thymuses from Mg-deficient rats, higher levels of apoptosis were observed, as compared with controls [53]. A Mg-deficient diet caused an alteration of polymorphonuclear cell number and functionality and an activation of phagocytosis [38]. $\mathrm{Mg}$ is involved in the regulation of cell apoptosis. Fas-induced $\beta$-cell apoptosis also requires $\mathrm{Mg}$. A raise in cellular free $\mathrm{Mg}$ levels is necessary for the expression of Fas molecule binding on the $\beta$-cell surface to trigger signaling pathways that initiate cellular apoptosis and death [54]. In addition, $\mathrm{Mg}$ is involved in the synthesis, transport and activation of vitamin $\mathrm{D}$, which is an important immunomodulator in several infectious diseases, including SARS-Cov2 infection [37]. Mg deficit may also be involved in other mechanisms described in COVID-19, such as the immune hyperresponsiveness with excessive release of inflammatory mediators leading to the cytokine storm, endothelial dysfunction, thrombotic complications, and pre-existent predisposing conditions that worsen the prognosis of COVID-19 clinical course, such as old age, diabetes and hypertension (see below).

\section{Clinical Symptoms Associated with Mg Deficits}

Clinical signs and symptoms are generally absent or non-specific in moderate $\mathrm{Mg}$ deficits and mild hypomagnesemic subjects are usually asymptomatic. Non-specific manifestations may include anxiety, insomnia, fatigue, hyperemotionality, depressive symptoms, headache, light-headedness, dizziness. Most of these symptoms are non-specific and common in older patients, and might be mistaken with normal age-related manifestations. Other symptoms may be associated, such as myalgias, acroparesthesias, and cramps. Other non-specific functional complaints may include chest pain, sine materia dyspnea, precordialgia, palpitations, extrasystoles and other arrhythmias, etc. [55].

Several signs and symptoms are connected with severe $\mathrm{Mg}$ deficits including weakness, tremor, muscle fasciculation, dysphagia, presence of Chvostek's sign (facial twitching as a reaction to the tapping of the facial nerve), or Trousseau's sign (spasm of muscles of the hand and forearm following the application of a pressure cuff, to transiently occlude the brachial artery), orthostatic hypotension and/or borderline hypertension [55].

Elin suggested naming the condition of subjects with this non-specific symptomatology associated with chronic, negative $\mathrm{Mg}$ balance as a syndrome of "Chronic Latent Mg Deficiency" (CLMD) [8]. Subjects affected by CLMD generally present lower normal total serum $\mathrm{Mg}$ levels (latent) and are generally clinically undiagnosed, not having hypomagnesemia, but may benefit from $\mathrm{Mg}$ supplementation.

\section{Hypothesis on the Possible Role of $\mathrm{Mg}$ in the Aging Process and Longevity}

$\mathrm{Mg}$ is crucial to preserve genomic stability in cellular systems, because of its stabilizing effects on DNA and chromatin structures. Thus, $\mathrm{Mg}$ ion is needed in nucleotide excision repair, base excision repair, and mismatch repair, and is crucial for the removal of DNA damage caused by endogenous processes, environmental mutagens, and DNA replication [56]. Mg deficiency triggers the cell vulnerability to oxidation and may affect immune system performance; a lack of $\mathrm{Mg}$ would alter membrane integrity and functionality and may facilitate mitochondrial alterations (decreased number, morphology 
modifications, increased apoptosis, increased DNA mutations, decreased biogenesis, decreased autophagy) [19]. Mg has an important role in the modulation of protein synthesis and membrane repair [56,57]. DNA is incessantly altered by endogenous processes and environmental mutagens. An increase in cellular $\mathrm{Mg}$ has been demonstrated in the early stages of apoptosis, possibly linked to a mobilization of $\mathrm{Mg}$ from the mitochondria; $\mathrm{Mg}$ may act as a "second messenger" for downstream events in apoptosis [54]. Mg deprivation increases the susceptibility to oxidative damage facilitating alterations of the membrane integrity and function.

Some alterations in cell physiology occurring in senescence in different cell types [58] are similar to those caused by $\mathrm{Mg}$ deficit. $\mathrm{Mg}$-depletion-related alterations include reduced protection from oxidative stress damage, reduced cell cycle progression, reduced culture growth, and reduced cellular viability as well as triggering of the expression of protooncogene and of transcription factors [59]. Culturing primary fibroblasts in Mg-deficient media would lower the replicative capacity and accelerate the expression of biomarkers associated with senescence and in telomere attrition. A decreased replicative lifespan was observed vs. fibroblast cultured in normal $\mathrm{Mg}$ media conditions [60].

Because of the essential role of $\mathrm{Mg}$ in the stabilization of DNA, in defending the cell to the damage of ROS and in stimulating DNA replication and transcription, a $\mathrm{Mg}$ deficit may facilitate genomic instability, alter DNA repair, and reduce mitochondria functionality, thus facilitating an accelerated cellular senescence and aging [56,61]. Mg has a demonstrated protective role against these effects and contrasts the shortening of telomeres (that is associated with aging and a reduced life expectancy), which is observed in low $\mathrm{Mg}$ conditions. It has been suggested that because of this action to prevent telomere shortening, correcting $\mathrm{Mg}$ deficiencies may prolong life [62].

\section{Mg in Hypertension and Cardiovascular Diseases}

In the last decades, $\mathrm{Mg}$ deficit has been connected with several cardiovascular conditions [2,63]. Kobayashi first noted in 1957 that the mineral composition of drinking water was associated with cardiovascular death rates; the stroke incidence was lower in regions with hard water (mainly linked to $\mathrm{Mg}$ and Ca content) [64]. Schroeder confirmed these data only a few years later, analyzing the relationship between water hardness and death rates. He found that cardiovascular death rates were significantly lower in states with hard water compared to states with soft water [65].

$\mathrm{Mg}$ is involved in blood pressure homeostasis. Although $\mathrm{Mg}$ has not a direct role in the biochemical mechanisms of contraction, classic studies from Altura et al. have demonstrated that $\mathrm{Mg}$ controls vascular tone and contractility by altering Ca levels, and that changes in $\mathrm{Mg}$ concentration modulates Ca-triggered vascular smooth muscle contraction [66-68]. Mg itself functions as nature's weak physiologic Ca channel blocker [69], modulating Ca-channel activity in heart cells [70]. Mg deficit stimulates angiotensin IImediated aldosterone synthesis, as well as thromboxane and vasoconstrictor prostaglandins production [71]. Mg has a favorable action on vascular endothelium modulating the release of nitric oxide, prostacyclin, and endothelin-1 [72]. In humans, oral Mg supplementation was shown to improve endothelial function in T2DM older adults [73].

$\mathrm{Mg}$ ion, because of these actions on vascular smooth muscle tone, plays a modulatory action on blood pressure homeostasis, while $\mathrm{Mg}$ deficits may be relevant to the physiopathology of hypertensive disorders. Altura showed that the depletion of $\mathrm{Mg}$ would induce vascular hyper-reactivity and elevation of blood pressure [74]. Serum total Mg levels are usually normal in hypertensive subjects. However, numerous defects of $\mathrm{Mg}$ homeostasis have been documented in hypertension. Former epidemiologic studies already showed an inverse relationship between $\mathrm{Mg}$ dietary intake and blood pressure [75]. In older populations, the age-related increase in blood pressure was concomitant with a reciprocal suppression of intracellular free $\mathrm{Mg}[29,76]$, suggesting a possible role for $\mathrm{Mg}$ deficit in the age-related elevation of blood pressure. Intracellular free $\mathrm{Mg}$ concentrations were found to be significantly lower in hypertensive subjects vs. normotensive controls [77]. $\mathrm{Mg}$ 
urinary excretion was also found to be altered in an experimental model of hypertensive rats [78]. High salt diet was reported to elevate blood pressure in salt-sensitive subjects, reciprocally suppressing intracellular free $\mathrm{Mg}$ levels [79].

Blackfan and Hamilton, as early as 1925, recommended Mg therapy to lower blood pressure in patients with malignant hypertension [80]. Intravenous (i.v.) $\mathrm{Mg}$ has been commonly used with consistent benefit in preeclampsia and in eclampsia [81], and in malignant hypertension [82]. However, the response to $\mathrm{Mg}$ oral supplement in essential hypertension is less clear [63,83-86]. In experimental hypertension, high or low Mg diets that, respectively, raised or reduced cellular free $\mathrm{Mg}$, in parallel reduced and raised blood pressure. In humans, in some studies, $\mathrm{Mg}$ supplementation was found to have hypotensive effects, while in others it had no effect on blood pressure or may even worsen it $[83,86]$. Nevertheless, when quality studies are analyzed together in meta-analysis and systematic reviews the evidence is convincing, validating the key role of $\mathrm{Mg}$ in hypertension and of an inverse relationship of dietary $\mathrm{Mg}$ intake with the prevalence and incidence of hypertension [63]. However, a possible confounding factor of the evidence derived from observational studies is that diets containing elevated $\mathrm{Mg}$ intake are also usually low in $\mathrm{Na}$ and rich in $\mathrm{K}$ and of other elements with health benefits and thus high Mg intake may be, at least in part, a marker of a healthy diet [63].

Thus, a reproducible and persistent hypotensive effect of oral $\mathrm{Mg}$ supplements on blood pressure has not been yet confirmed in large long-term prospective trials in essential hypertension and further data are necessary to advise $\mathrm{Mg}$ supplementation as a nonpharmacological strategy for hypertension prevention and/or treatment purposes. There are several possible explanations for this uncertainty. Among them: (a) the virtual absence of specifically planned clinical prospective trials of $\mathrm{Mg}$ treatment in hypertension; (b) the different dosages and therapy schedules used in a number of smaller clinical reports; and (c) a failure to detect the heterogeneity of the underlying mechanisms causing the raise in blood pressure. Hence, long-term longitudinal therapeutic trials of oral $\mathrm{Mg}$ supplements in essential hypertension are required.

$\mathrm{Mg}$ deficit has been linked to the development of atherosclerosis. Low Mg status may trigger vascular calcification, alter lipid metabolism and facilitate lipid accumulation in vascular plaques [87]. Serum $\mathrm{Mg}$ was found to be positively [88] or negatively [89] associated with serum lipid levels. Mg supplementation has been suggested to improve lipid profiles, and prevent atherosclerotic plaque formation and to act as a weak inhibitor of hydroxyl-3-methylglutaryl-coenzyme A reductase, and of other enzymes of the lipid metabolism [90].

$\mathrm{Mg}$ is involved in the heart's electrical conduction and hypomagnesemia, hypokalemia and other electrolyte disturbances may trigger cardiac arrhythmias. $\mathrm{Mg}$ and $\mathrm{K}$ depletion also increase the susceptibility to arrhythmogenic effects of cardiac glycosides.

$\mathrm{Mg}$ effects on conduction comprise prolongation of atrial and atrioventricular nodal refractory periods, which may help in rate and rhythm control in atrial fibrillation (AF) [91]. $\mathrm{Mg}$ supplements may be used as a supportive non-pharmacological treatment for atrial and/or ventricular arrhythmias [92]. AF may be associated with hypomagnesemia [93] and reduced serum $\mathrm{Mg}$ concentration may facilitate the development of AF [94].

In postmenopausal women, dietary Mg deficiency was associated with heart rhythm abnormalities, including AF and flutter that may respond to Mg supplementation [95]. A meta-analysis has suggested that i.v. $\mathrm{Mg}$ administration may have a role in the acute management of AF [96]. Because of its rapid, effective and simple application, i.v. $\mathrm{Mg}$ administration has been indicated in the treatment of torsade de pointes $[97,98]$. Antiarrhythmic actions of elevated $\mathrm{Mg}$ dietary intake have been suggested to mediate the reduced risk of sudden death in women in the highest quartile of $\mathrm{Mg}$ intake [99].

Oral $\mathrm{Mg}$ supplements were suggested to help improving clinical symptoms and survival outcomes vs. placebo in patients with severe congestive heart failure [100].

A systematic review and meta-analysis of prospective studies that included over 300,000 individuals found that elevated $\mathrm{Mg}$ serum levels paralleled a reduced risk of 
cardiovascular disease; elevated dietary $\mathrm{Mg}$ intakes were shown to be inversely associated with ischemic heart disease [101].

Another meta-analysis of prospective trials including a total of 241,378 subjects reported an inverse association between $\mathrm{Mg}$ intake and the risk of stroke [102]. A recent umbrella review evaluating health outcomes connected with $\mathrm{Mg}$ intake and supplementation confirmed the link between higher $\mathrm{Mg}$ intake and decreased risk of stroke [86].

$\mathrm{Mg}$ sulfate has been found to be protective both in preclinical models of stroke and in humans. Mg has been suggested to have some potential efficacy, and a good safety profile if delivered i.v. early after stroke onset [103].

\section{Mg in Type 2 Diabetes}

A consistent body of evidence has linked $\mathrm{Mg}$ deficiency to alterations of insulin sensitivity and T2DM. Indeed, T2DM has been associated with several extra-and intra-cellular $\mathrm{Mg}$ abnormalities [2,104-106]. Lower cellular and/or ionized plasma Mg concentrations have been found in patients with T2DM despite still normal less sensitive total serum Mg levels [107,108]. Possible mechanisms favoring Mg depletion in T2DM include a low $\mathrm{Mg}$ dietary intake and an increased $\mathrm{Mg}$ urinary loss, while the absorption and retention of dietary Mg seem to be unchanged [109]. It has been reported an inverse relationship between $\mathrm{Mg}$ intake and the incidence of new cases of T2DM. Both hyperglycemia and hyperinsulinemia have been implicated in contributing to $\mathrm{Mg}$ depletion [110]. Both, hyperglycemia and hyperinsulinemia favor an excessive urinary Mg excretion, while insulin resistance may alter $\mathrm{Mg}$ transport [111]. Altered $\mathrm{Mg}$ metabolism may predispose to the development of T2DM and to an impairment of insulin-mediated glucose uptake [2].

Because of these pieces of evidence, $\mathrm{Mg}$ supplementation has been suggested as a possible non-pharmacologic, economic and safe treatment for the prevention and the metabolic control of T2DM. However, prospective trials concerning the effects of $\mathrm{Mg}$ supplementation in people with or at risk of T2DM are limited [112,113]. A modest beneficial effect of $\mathrm{Mg}$ supplements on glycemic profiles have been found in many, but not all, studies. A systematic review and meta-analysis including 18 double-blind randomized controlled trials (12 in subjects with diabetes and six in subjects at elevated risk of T2DM) reported that $\mathrm{Mg}$ supplementation may have some beneficial actions improving glucose parameters in people with T2DM and to improve insulin-sensitivity parameters in subjects at high risk of T2DM [114]. Using an umbrella review to map and grade health outcomes linked to $\mathrm{Mg}$ intake and supplementation, our group recently confirmed that an elevated $\mathrm{Mg}$ intake is associated with a decreased risk of T2DM [86].

\section{Mg in Cardiometabolic Syndrome}

There are also convincing proofs of a link of $\mathrm{Mg}$ deficit with metabolic syndrome [2,6,115]. In epidemiological studies, dietary $\mathrm{Mg}$ inadequacy has been connected with an increased risk of glucose intolerance, metabolic syndrome, and T2DM [115-117]. Intracellular Mg deficit, causing a defective activity of all the Mg-dependent kinases involved in the insulin signaling, and increasing oxidative stress would favor insulin resistance and resulting metabolic conditions, including glucose intolerance, metabolic syndrome and T2DM.

Mg-deprivation in sheep caused an impairment of insulin-mediated glucose uptake [118], while Mg supplementation delayed the development of the disease in a rat model of diabetes [119]. Lower fasting insulin levels were found in healthy women without diabetes with higher $\mathrm{Mg}$ intakes [120]. Total dietary Mg intakes were inversely related to insulin responses to an oral glucose tolerance test [121].

\section{Mg and Asthma and Respiratory Insufficiency}

First, Haury in 1940 proposed a role for Mg in asthma showing a beneficial clinical response after i.v. $\mathrm{Mg}$ sulfate administration in two hospitalized patients having acute exacerbations of asthma [122]. In the following decades, other reports confirmed positive results of $\mathrm{Mg}$ i.v. treatment in acute airway constriction, suggesting a possible beneficial 
action of Mg in the mechanism of bronchial dilation [123,124], although other reports did not confirm the therapeutic effect $[125,126]$. Administration of i.v. Mg seems to increase, in an additive fashion, the bronchial dilating effect of terbutaline [127] and salbutamol [128] in improving functional pulmonary tests.

Mg modulates the contractile state of bronchial smooth muscle cells; Mg depletion triggers bronchial contraction and spasm, while $\mathrm{Mg}$ restoration produces bronchial relaxation. Several possible mechanisms have been postulated for the positive $\mathrm{Mg}$ action to relax bronchial smooth muscle, such as the Ca channel blocking action of Mg [69], a decreased sensibility to the depolarizing action of acetylcholine [92], a stabilization of mast cells and T-lymphocytes [129], and a stimulation of nitric oxide [130] and prostacyclin [131]. In the general population, significant positive independent associations of dietary $\mathrm{Mg}$ intake with lung function and inverse associations with airway reactivity, inhaled methacholine, and respiratory symptoms (wheezing) have been reported, suggesting that a low $\mathrm{Mg}$ intake may be implicated in the etiology of asthma [132].

However, total $\mathrm{Mg}$ serum levels are not clinically useful, since no differences were found in serum $\mathrm{Mg}$ in patients with asthma during acute exacerbation compared to a non-asthmatic population and serum total $\mathrm{Mg}$ is not predictive of the severity of the asthmatic attacks, or of the bronchial dilating response to $\mathrm{Mg}$ infusion [133]. Conversely, cellular $\mathrm{Mg}$ (more related to body Mg status) was found to be reduced in asthmatic subjects when compared to non-asthmatic controls [134]. In addition, our group demonstrated a direct correlation, in asthmatic patients, between cellular $\mathrm{Mg}$ levels and the methacholine bronchial reactivity confirming the presence of intracellular $\mathrm{Mg}$ alterations in asthma and have proposed an additive role for a non-pharmacological $\mathrm{Mg}$ supplementation in asthmatic patients [135].

Altogether, the available data suggest a role for cellular and body $\mathrm{Mg}$ deficit as a modulator of smooth muscle bronchial reactivity and contractility, facilitating bronchoconstriction in predisposed asthmatic subjects, and a possible preventive and/or therapeutic role for additive use of $\mathrm{Mg}$ administration in these persons [136].

\section{Mg and Psychiatric Disorders}

Several psychiatric disorders including anxiety, depression, irritability, insomnia, hypochondriasis, panic attacks, hyperexcitability, headache, dizziness, tremors, and psychotic behavior have been associated with $\mathrm{Mg}$ deficiency. Neuromuscular symptoms may be associated, including asthenia, muscular weakness, and myalgias (e.g., chronic fatigue syndrome and fibromyalgia) [137].

A number of enzymes and cellular reactions involved in stress responses are $\mathrm{Mg}$ dependent [15]. Serum Mg levels have been proposed to be reduced in subjects with depression [138]. A recent study by Noah et al. showed that nearly half (forty-four percent) of patients screened for stress had a latent $\mathrm{Mg}$ insufficiency [139].

$\mathrm{Mg}$ deficit may produce electrophysiological evidence of hyperexcitability in the central nervous system (CNS). In Mg deficient rats, electroencephalogram (EEG) modifications were monitored during auditory stimuli. Several alterations with spike activity were found in the EEG, suggesting that auditory stimulation induced behavioral changes in $\mathrm{Mg}$-deficient rats, which may be linked to $\mathrm{Mg}$ related-increased excitability of the CNS [140].

In humans, $\mathrm{Mg}$ insufficiency has been connected with neuro-muscular hyperexcitability [141]. Various possible mechanisms may link Mg deficiency to nervous hyperexcitability, such as the previously described $\mathrm{Mg}$ modulatory actions on cellular $\mathrm{Ca}$, the increased peroxidation, the hyper-activation of some excitatory neurotransmitters, (i.e., acetylcholine, catecholamines, NMDA and non-NMDA receptors of excitatory aminoacids), and a decreased activity of inhibitory neurotransmitters (i.e., gamma-aminobutyric acid (GABA), taurine, glutaurine, adenosine), as well as an increased production of neuropeptides, inflammatory cytokines, prostanoids, and a decreased activity of anti-oxidant defenses [137]. 
In relation to these links with the transduction and biological pathways implicated in depression, and because of the modulatory role of $\mathrm{Mg}$ on the ion channel of the NMDAreceptor complex [142], Mg supplements have been proposed to be helpful in the treatment of depression $[143,144]$. Some antidepressant drugs such as sertraline and amitriptyline have been suggested to increase intracellular Mg levels [145]. A systematic review showed that higher $\mathrm{Mg}$ intakes were associated with reduced depression symptoms [144]. Oral $\mathrm{Mg}$ supplements may provide advantage in the prevention of depressive symptoms and may be supportive as an adjunctive therapy. The effect of $\mathrm{Mg}$ supplementation on stress and anxiety is less documented. However, more interventional and prospective studies are needed in order to establish a clear role for $\mathrm{Mg}$ supplementation as a possible adjunct care in the treatment of depression, and other psychiatric disorders.

$\mathrm{Mg}$ has also been suggested as an adjuvant treatment in the therapy of insomnia. $\mathrm{Mg}$, in addition to being a natural NMDA antagonist and a GABA agonist, also has a relaxant action, and may increase melatonin levels, thus helping to improve sleep [146].

\section{Mg and Cognitive Decline}

A possible protective action of $\mathrm{Mg}$ in cognitive deterioration and $\mathrm{AD}$ was already suggested in 1990 [147]. Mg ion is important for a normal neuronal maturation and is present in the cerebrospinal fluid (CSF) in the CNS [148]. Mg passes the blood-brain barrier, and is actively transported by choroidal epithelial cells into the CSF [148].

Alterations of $\mathrm{Mg}$ metabolism are present in patients with dementia: total and ionized serum $\mathrm{Mg}$ levels, and various tissues $\mathrm{Mg}$ content have all consistently be found reduced in patients with AD [149-152].

$\mathrm{Mg}$ concentrations in the brain affect multiple biochemical processes involved in cognitive functions, including cell membrane stability and integrity, NMDA-receptor response to excitatory stimuli, and Ca-antagonist action [19]. It has been suggested that the neurotoxic effect of some metals, such as aluminum, may be related to an alteration of the incorporation of $\mathrm{Mg}$ into brain neurons, thus impairing $\mathrm{Mg}$ protective effects on brain tissue [147]. $\mathrm{Mg}$ has been reported to expedite toxin clearance, reduce neuroinflammation, inhibit the pathologic processing of amyloid protein precursor, inhibit abnormal tau protein phosphorylation, and reverse deregulation of NMDA receptors. However, the mechanisms of these effects are not completely clear [153].

$\mathrm{Mg}$-L-threonate administration has been reported to reduce neuroinflammation and decrease beta-amyloid deposition in experimental models of AD [154,155], and to enhance learning abilities, working and short- and long-term memory in rats [156]. Experimental animal studies are promising and may suggest that $\mathrm{Mg}$ supplementation if started at the early stages of cognitive deficits may decrease the slope of memory fall and cognitive decline [157].

In humans, only a few clinical trials have studied the role of $\mathrm{Mg}$ in cognitive health. Epidemiologically, it has been suggested that people consuming diets rich in $\mathrm{Mg}$ may have a reduced risk of cognitive decline. In 1400 healthy adult men followed for eight years, elevated dietary $\mathrm{Mg}$ intakes were associated with a reduced risk of developing mild cognitive impairment [158]. In another cohort study including more than 1000 communitydwelling Japanese participants aged over 60 years and followed for 17 years, it was found that those who were assuming more than $200 \mathrm{mg} /$ day of $\mathrm{Mg}$ had thirty-seven percent less chances to develop any type of dementia and seventy four percent less chances to develop vascular dementia [159]. A short-term (12 weeks) randomized controlled trial suggested that $\mathrm{Mg}$ may help in improving cognitive abilities in elderly subjects with memory complaints [160]. Long-term prospective randomized clinical trials with $\mathrm{Mg}$ supplementation are needed to confirm if $\mathrm{Mg}$-rich diets may help in preventing dementia and/or cognitive impairment. 


\section{Mg and Osteoporosis}

Dietary Mg deficit has been hypothesized as a potential risk factor for osteoporotic disease and bone loss. Epidemiologic studies have shown that elevated dietary intakes of $\mathrm{Mg}$ were positively and significantly related to bone mineral density (BMD). On the opposite, inadequate dietary $\mathrm{Mg}$ intakes were linked to an increased rate of bone loss in postmenopausal osteoporotic women [161,162]. In the Health, Aging and Body Composition Study, it was observed that higher Mg intakes were associated with higher BMD in healthy white participants, aged 70 to 79 years at baseline [163]. Following a selective dietary $\mathrm{Mg}$ deprivation, $\mathrm{Mg}$-depleted mice with frank hypomagnesemia developed osteoporosis, increased skeletal fragility associated with increased bone resorption, decreased bone formation, and impaired bone growth $[164,165]$. Elevated concentrations of inflammatory cytokines may play a role in explaining these bone alterations, although a clear pathophysiologic link remains undefined. Rude and Gruber showed that an increased osteoclastic bone resorption was associated with increased levels of inflammatory substance $\mathrm{P}$ and TNF-alfa in bone from Mg-deficient rats [166].

In addition, $\mathrm{Mg}$ is necessary for vitamin $\mathrm{D}$ synthesis, transport, and activation; hence, $\mathrm{Mg}$ deficits would impair the production of the active form of vitamin D, 1,25-OH2 D3, and cause a resistance to PTH and vitamin D actions [167]. The effects of Mg deficiency added together with an altered PTH responsiveness and low 1,25-OH2 D3 synthesis would impair the bone formation and mineralization processes and would reduce the quality, and strength of the bone as well as the BMD. It has been hypothesized that $\mathrm{Mg}$ supplementation in doses sufficient to restore a normal bone turnover may reduce the bone loss and prevent the risk of osteoporosis $[168,169]$.

In participants to the cohort "Osteoarthritis Initiative" followed for 8 years, it was found that women with the higher dietary $\mathrm{Mg}$ intake had a twenty-seven percent reduced risk for future fractures, confirming the positive role of maintaining an adequate $\mathrm{Mg}$ balance on the risk of osteoporosis and fragility fractures [170].

\section{Mg and the Muscle Health}

Mg ion has a key role in all enzymes utilizing or synthesizing muscle ATP, and thus in the production of muscle energy, and indirectly in the contraction and relaxation processes. $\mathrm{Mg}$ deficit has been related to a poor muscle performance.

Severe Mg deficits have been suggested to cause weakness, muscle pain and night cramps. It has been proposed that $\mathrm{Mg}$ deficit may contribute to the development of fibromyalgia [171]. Data on the effects of $\mathrm{Mg}$ supplements in fibromyalgia symptoms are scarce, although it was suggested that $\mathrm{Mg}$ supplements may be used to reduce tenderness, pain, and symptom severity in fibromyalgic subjects [172].

Dietary $\mathrm{Mg}$ deficiency in rats boosts the production of free radical in skeletal muscle and may cause several alterations in muscle cell metabolism together with structural impairments affecting the production of muscle energy needed for muscle contraction and relaxation [173].

In humans, Dominguez et al., showed a strong and independent relationship between serum $\mathrm{Mg}$ levels with muscle performance and several muscle parameters [174]. In young volunteers, Brilla et al. showed that $\mathrm{Mg}$ supplements (up to $8 \mathrm{mg} / \mathrm{kg}$ daily) were able to enhance muscle strength and endurance performance, and to reduce the oxygen consumption [175]. In older subjects, Veronese et al. showed that oral Mg supplementation (three hundred $\mathrm{mg}$ /day) was able to improve the physical performance, in particular in those subjects with a baseline low Mg dietary intake, proposing that Mg supplementation may help in preventing or delaying the decline in physical performance with age [176].

\section{7. $\mathrm{Mg}$ and Cancer}

In regard to cancer, $\mathrm{Mg}$ intake has been connected with the incidence of some cancers. However, the relation between $\mathrm{Mg}$ and cancer is complex, and nowadays there are more questions than answers [177]. In animal models, $\mathrm{Mg}$ may exert both anti- and pro-tumor 
effects such as inhibition of tumor growth at its primary site and facilitation of tumor implantation at its metastatic sites. In Mg-deficient mice, low $\mathrm{Mg}$ may both restrict and foster tumorigenesis, since inhibition of tumor growth at its primary site is observed in the face of increased metastatic colonization [177].

Oxidative stress and trace elements have been implicated in the development of breast cancer. However, how they impact the pathogenesis of the disease remain unclear [178]. Lower serum $\mathrm{Mg}$ levels in women with breast cancer may compromise the antioxidant defense systems involved in the carcinogenesis process. A study evaluated Mg metabolism, the superoxide dismutase activity, and its relation with oxidation stress in women with breast cancer. The authors reported that breast cancer patients display a complex alteration of $\mathrm{Mg}$ homeostasis, characterized by low dietary $\mathrm{Mg}$ intakes, reduced plasma, and erythrocytes $\mathrm{Mg}$ levels and an increase in $\mathrm{Mg}$ excretion in the urine [179].

$\mathrm{Mg}$ supplementation may have a protective effect on experimentally induced fibrosarcoma in rats [180], and may inhibit nickel-induced carcinogenesis in the rat kidney [181].

$\mathrm{Mg}$ has been suggested to have anti-tumor effects in colorectal cancer by inhibiting c-myc expression and ornithine decarboxylase activity in the mucosal epithelium of the intestine [182]. In human studies, high dietary Mg consumption has been suggested to be protective for the risk of developing colorectal cancer [183]. In postmenopausal women, it has been proposed that a higher ratio of serum $\mathrm{Ca}$ to $\mathrm{Mg}$ may increase the risk for breast cancer [184]. Ca, Mg or Ca:Mg intake ratio may interact with polymorphisms in the SLC7A2 gene in associations with colorectal cancer [185].

Higher Mg intake was associated with a lower risk of liver cancer, based on an analysis of the National Institute of Health-American Association of Retired Persons (NIH-AARP) Diet and Health Study prospective cohort [186].

One of the reasons that the independent relationship of $\mathrm{Mg}$ intake and cancer protection is not easy to define is because dietary $\mathrm{Mg}$ content parallels fiber content and is mostly obtained from green leafy vegetables and whole cereals, rich sources of fiber, that are themselves cancer protective.

\section{Conclusions}

A chronic Mg deficiency is frequently present in older adults. Low-grade chronic inflammation (inflammaging) is frequently present in numerous age-related chronic diseases, and with the aging process itself. Since a chronic Mg inadequacy may cause an exaggerated production of inflammatory mediators and ROS, and it may trigger an inflammatory state, our group has previously hypothesized that the chronic Mg insufficiency may be one of the mediators helping to explain the link between inflammaging and aging-related diseases [19,49] (Figure 2). It is possible to hypothesize that preserving an optimal $\mathrm{Mg}$ balance during the course of life may help to prevent inflammaging and related conditions associated with $\mathrm{Mg}$ inadequacy and may thus help to lengthen healthy life.

However, while it is advisable to maintain a satisfactory $\mathrm{Mg}$ balance with a sufficient dietary intake of $\mathrm{Mg}$, the possible role of $\mathrm{Mg}$ supplements is still unclear.

Very few long-term longitudinal blind studies on the effects of $\mathrm{Mg}$ supplementation have been performed. The possibility that maintaining a satisfactory $\mathrm{Mg}$ balance throughout life may become an economic and safe health strategy in the growing aging population is a suggestive hypothesis that needs to be proven by future prospective studies.

Author Contributions: Writing-original draft preparation and writing M.B.; writing-review and editing, L.J.D., N.V. All authors have read and agreed to the published version of the manuscript.

Funding: This research received no external funding.

Institutional Review Board Statement: Not applicable.

Informed Consent Statement: Not applicable.

Data Availability Statement: No new data were created or analyzed in this study. Data sharing is not applicable to this article. 
Conflicts of Interest: The authors declare no conflict of interest.

\section{References}

1. Saris, N.E.; Mervaala, E.; Karppanen, H.; Khawaja, J.A.; Lewenstam, A. Magnesium. An update on physiological, clinical and analytical aspects. Clin. Chim. Acta 2000, 294, 1-26. [CrossRef]

2. Barbagallo, M.; Dominguez, L.J. Magnesium metabolism in type 2 diabetes mellitus, metabolic syndrome and insulin resistance. Arch. Biochem. Biophys. 2007, 458, 40-47. [CrossRef] [PubMed]

3. Reinhart, R.A. Magnesium metabolism. A review with special reference to the relationship between intracellular content and serum levels. Arch. Intern. Med. 1988, 148, 2415-2420. [CrossRef] [PubMed]

4. Resnick, L.M.; Barbagallo, M.; Dominguez, L.J.; Veniero, J.M.; Nicholson, J.P.; Gupta, R.K. Relation of cellular potassium to other mineral ions in hypertension and diabetes. Hypertension 2001, 38 Pt 2, 709-712. [CrossRef]

5. Reddy, S.T.; Soman, S.S.; Yee, J. Magnesium Balance and Measurement. Adv. Chronic Kidney Dis. 2018, 25, 224-229. [CrossRef]

6. Barbagallo, M.; Dominguez, L.J.; Galioto, A.; Ferlisi, A.; Cani, C.; Malfa, L.; Pineo, A.; Busardo, A.; Paolisso, G. Role of magnesium in insulin action, diabetes and cardio-metabolic syndrome X. Mol. Asp. Med. 2003, 24, 39-52. [CrossRef]

7. de Baaij, J.H.; Hoenderop, J.G.; Bindels, R.J. Magnesium in man: Implications for health and disease. Physiol. Rev. 2015, 95, 1-46. [CrossRef]

8. Elin, R.J. Assessment of magnesium status for diagnosis and therapy. Magnes. Res. 2010, 23, S194-S198.

9. Department of Health and Human Services. US Department of Agriculture (2015) 2015-2020 Dietary Guidelines for Americans, 8th ed.; Department of Health and Human Services: Washington, DC, USA, 2020.

10. Quamme, G.A. Recent developments in intestinal magnesium absorption. Curr. Opin. Gastroenterol. 2008, 24, 230-235. [CrossRef]

11. Shils, M.E. Experimental production of magnesium deficiency in man. Ann. N. Y. Acad. Sci. 1969, 162, 847-855. [CrossRef]

12. Quamme, G.A. Renal magnesium handling: New insights in understanding old problems. Kidney Int. 1997, 52, 1180-1195. [CrossRef] [PubMed]

13. Barbagallo, M.; Dominguez, L.J.; Resnick, L.M. Magnesium metabolism in hypertension and type 2 diabetes mellitus. Am. J. Ther. 2007, 14, 375-385. [CrossRef] [PubMed]

14. DiNicolantonio, J.J.; O'Keefe, J.H.; Wilson, W. Subclinical magnesium deficiency: A principal driver of cardiovascular disease and a public health crisis. Open Heart 2018, 5, e000668. [CrossRef] [PubMed]

15. Pickering, G.; Mazur, A.; Trousselard, M.; Bienkowski, P.; Yaltsewa, N.; Amessou, M.; Noah, L.; Pouteau, E. Magnesium Status and Stress: The Vicious Circle Concept Revisited. Nutrients 2020, 12, 3672. [CrossRef]

16. King, D.E.; Mainous, A.G., III; Geesey, M.E.; Woolson, R.F. Dietary magnesium and C-reactive protein levels. J. Am. Coll. Nutr. 2005, 24, 166-171. [CrossRef]

17. Michalczyk, M.M.; Zajac-Gawlak, I.; Zajac, A.; Pelclova, J.; Roczniok, R.; Langfort, J. Influence of Nutritional Education on the Diet and Nutritional Behaviors of Elderly Women at the University of the Third Age. Int. J. Environ. Res. Public Health 2020, 17, 696. [CrossRef]

18. Durlach, J.; Bara, M.; Guiet-Bara, A. Magnesium level in drinking water and cardiovascular risk factor: A hypothesis. Magnesium 1985, 4, 5-15.

19. Barbagallo, M.; Dominguez, L.J. Magnesium and aging. Curr. Pharm. Des. 2010, 16, 832-839. [CrossRef]

20. Russell, J.B. Enrichment and Isolation of Rumen Bacteria That Reduce trans-Aconitic Acid to Tricarballylic Acid. Appl. Environ. Microbiol. 1985, 49, 120-126. [CrossRef]

21. Schwartz, R.; Topley, M.; Russell, J.B. Effect of tricarballylic acid, a nonmetabolizable rumen fermentation product of trans-aconitic acid, on Mg, Ca and Zn utilization of rats. J. Nutr. 1988, 118, 183-188. [CrossRef]

22. Cakmak, I.; Yazici, M.A.; Tutus, Y.; Ozturk, L. Glyphosate reduced seed and leaf concentrations of calcium, manganese, magnesium, and iron in non-glyphosate resistant soybean. Eur. J. Agron. 2009, 31, 114-119. [CrossRef]

23. Griffiths, A.M.; Cook, D.M.; Eggett, D.L.; Christensen, M.J. A retail market study of organic and conventional potatoes (Solanum tuberosum): Mineral content and nutritional implications. Int. J. Food Sci. Nutr. 2012, 63, 393-401. [CrossRef] [PubMed]

24. Oey, S.B.; van der Fels-Klerx, H.J.; Fogliano, V.; van Leeuwen, S.P.J. Mitigation Strategies for the Reduction of 2- and 3-MCPD Esters and Glycidyl Esters in the Vegetable Oil Processing Industry. Compr. Rev. Food Sci. Food Saf. 2019, 18, 349-361. [CrossRef] [PubMed]

25. Galan, P.; Arnaud, M.J.; Czernichow, S.; Delabroise, A.M.; Preziosi, P.; Bertrais, S.; Franchisseur, C.; Maurel, M.; Favier, A.; Hercberg, S. Contribution of mineral waters to dietary calcium and magnesium intake in a French adult population. J. Am. Diet. Assoc. 2002, 102, 1658-1662. [CrossRef]

26. Koren, G.; Shlezinger, M.; Katz, R.; Shalev, V.; Amitai, Y. Seawater desalination and serum magnesium concentrations in Israel. J. Water Health 2017, 15, 296-299. [CrossRef]

27. Shlezinger, M.; Amitai, Y.; Goldenberg, I.; Shechter, M. Desalinated seawater supply and all-cause mortality in hospitalized acute myocardial infarction patients from the Acute Coronary Syndrome Israeli Survey 2002-2013. Int. J. Cardiol. 2016, 220, 544-550. [CrossRef]

28. Yang, X.Y.; Hosseini, J.M.; Ruddel, M.E.; Elin, R.J. Blood magnesium parameters do not differ with age. J. Am. Coll. Nutr. 1990, 9 , 308-313. [CrossRef] 
29. Barbagallo, M.; Gupta, R.K.; Dominguez, L.J.; Resnick, L.M. Cellular ionic alterations with age: Relation to hypertension and diabetes. J. Am. Geriatr. Soc. 2000, 48, 1111-1116. [CrossRef]

30. Ford, E.S.; Mokdad, A.H. Dietary magnesium intake in a national sample of US adults. J. Nutr. 2003, 133, 2879-2882. [CrossRef]

31. Galan, P.; Preziosi, P.; Durlach, V.; Valeix, P.; Ribas, L.; Bouzid, D.; Favier, A.; Hercberg, S. Dietary magnesium intake in a French adult population. Magnes. Res. 1997, 10, 321-328.

32. Hunt, C.D.; Johnson, L.K. Magnesium requirements: New estimations for men and women by cross-sectional statistical analyses of metabolic magnesium balance data. Am. J. Clin. Nutr. 2006, 84, 843-852. [CrossRef] [PubMed]

33. Coudray, C.; Feillet-Coudray, C.; Rambeau, M.; Tressol, J.C.; Gueux, E.; Mazur, A.; Rayssiguier, Y. The effect of aging on intestinal absorption and status of calcium, magnesium, zinc, and copper in rats: A stable isotope study. J. Trace Elem. Med. Biol. 2006, 20, 73-81. [CrossRef] [PubMed]

34. Grober, U. Magnesium and Drugs. Int. J. Mol. Sci. 2019, 20, 2094. [CrossRef] [PubMed]

35. Mazur, A.; Maier, J.A.; Rock, E.; Gueux, E.; Nowacki, W.; Rayssiguier, Y. Magnesium and the inflammatory response: Potential physiopathological implications. Arch. Biochem. Biophys. 2007, 458, 48-56. [CrossRef] [PubMed]

36. Malpuech-Brugere, C.; Nowacki, W.; Daveau, M.; Gueux, E.; Linard, C.; Rock, E.; Lebreton, J.; Mazur, A.; Rayssiguier, Y. Inflammatory response following acute magnesium deficiency in the rat. Biochim. Biophys. Acta 2000, 1501, 91-98. [CrossRef]

37. Dominguez, L.J.; Veronese, N.; Guerrero-Romero, F.; Barbagallo, M. Magnesium in Infectious Diseases in Older People. Nutrients 2021, 13, 180. [CrossRef]

38. Bussiere, F.I.; Tridon, A.; Zimowska, W.; Mazur, A.; Rayssiguier, Y. Increase in complement component C3 is an early response to experimental magnesium deficiency in rats. Life Sci. 2003, 73, 499-507. [CrossRef]

39. Kramer, J.H.; Mak, I.T.; Phillips, T.M.; Weglicki, W.B. Dietary magnesium intake influences circulating pro-inflammatory neuropeptide levels and loss of myocardial tolerance to postischemic stress. Exp. Biol. Med. 2003, 228, 665-673. [CrossRef]

40. Song, Y.; Li, T.Y.; van Dam, R.M.; Manson, J.E.; Hu, F.B. Magnesium intake and plasma concentrations of markers of systemic inflammation and endothelial dysfunction in women. Am. J. Clin. Nutr. 2007, 85, 1068-1074. [CrossRef]

41. Guerrero-Romero, F.; Bermudez-Pena, C.; Rodriguez-Moran, M. Severe hypomagnesemia and low-grade inflammation in metabolic syndrome. Magnes. Res. 2011, 24, 45-53. [CrossRef]

42. Song, Y.; Ridker, P.M.; Manson, J.E.; Cook, N.R.; Buring, J.E.; Liu, S. Magnesium intake, C-reactive protein, and the prevalence of metabolic syndrome in middle-aged and older U.S. women. Diabetes Care 2005, 28, 1438-1444. [CrossRef] [PubMed]

43. Weglicki, W.B.; Mak, I.T.; Kramer, J.H.; Dickens, B.F.; Cassidy, M.M.; Stafford, R.E.; Philips, T.M. Role of free radicals and substance $\mathrm{P}$ in magnesium deficiency. Cardiovasc. Res. 1996, 31, 677-682. [CrossRef]

44. Tohidi, M.; Ghasemi, A.; Hadaegh, F.; Arbabi, S.; Hosseini Isfahani, F. Intra-erythrocyte magnesium is associated with gammaglutamyl transferase in obese children and adolescents. Biol. Trace Elem. Res. 2011, 143, 835-843. [CrossRef] [PubMed]

45. Weglicki, W.B.; Bloom, S.; Cassidy, M.M.; Freedman, A.M.; Atrakchi, A.H.; Dickens, B.F. Antioxidants and the cardiomyopathy of Mg-deficiency. Am. J. Cardiovasc. Pathol. 1992, 4, 210-215.

46. Barbagallo, M.; Dominguez, L.J.; Tagliamonte, M.R.; Resnick, L.M.; Paolisso, G. Effects of glutathione on red blood cell intracellular magnesium: Relation to glucose metabolism. Hypertension 1999, 34, 76-82. [CrossRef]

47. Cernak, I.; Savic, V.; Kotur, J.; Prokic, V.; Kuljic, B.; Grbovic, D.; Veljovic, M. Alterations in magnesium and oxidative status during chronic emotional stress. Magnes. Res. 2000, 13, $29-36$.

48. Franceschi, C.; Garagnani, P.; Vitale, G.; Capri, M.; Salvioli, S. Inflammaging and 'Garb-aging'. Trends Endocrinol. Metab. 2017, 28, 199-212. [CrossRef]

49. Barbagallo, M.; Belvedere, M.; Dominguez, L.J. Magnesium homeostasis and aging. Magnes. Res. 2009, 22, 235-246. [CrossRef]

50. Tam, M.; Gomez, S.; Gonzalez-Gross, M.; Marcos, A. Possible roles of magnesium on the immune system. Eur. J. Clin. Nutr. 2003, 57, 1193-1197. [CrossRef]

51. Feske, S.; Skolnik, E.Y.; Prakriya, M. Ion channels and transporters in lymphocyte function and immunity. Nat. Rev. Immunol. 2012, 12, 532-547. [CrossRef]

52. Schmitz, C.; Perraud, A.L.; Johnson, C.O.; Inabe, K.; Smith, M.K.; Penner, R.; Kurosaki, T.; Fleig, A.; Scharenberg, A.M. Regulation of vertebrate cellular $\mathrm{Mg}^{2+}$ homeostasis by TRPM7. Cell 2003, 114, 191-200. [CrossRef]

53. Malpuech-Brugere, C.; Nowacki, W.; Gueux, E.; Kuryszko, J.; Rock, E.; Rayssiguier, Y.; Mazur, A. Accelerated thymus involution in magnesium-deficient rats is related to enhanced apoptosis and sensitivity to oxidative stress. Br. J. Nutr. 1999, 81, 405-411. [CrossRef] [PubMed]

54. Chien, M.M.; Zahradka, K.E.; Newell, M.K.; Freed, J.H. Fas-induced B cell apoptosis requires an increase in free cytosolic magnesium as an early event. J. Biol. Chem. 1999, 274, 7059-7066. [CrossRef] [PubMed]

55. Flink, E.B. Magnesium deficiency. Etiology and clinical spectrum. Acta Med. Scand. Suppl. 1981, 647, 125-137. [CrossRef] [PubMed]

56. Hartwig, A. Role of magnesium in genomic stability. Mutat. Res. 2001, 475, 113-121. [CrossRef]

57. Rubin, H. Magnesium: The missing element in molecular views of cell proliferation control. Bioessays 2005, 27, 311-320. [CrossRef]

58. Blackburn, E.H. Telomere states and cell fates. Nature 2000, 408, 53-56. [CrossRef]

59. Sgambato, A.; Wolf, F.I.; Faraglia, B.; Cittadini, A. Magnesium depletion causes growth inhibition, reduced expression of cyclin D1, and increased expression of P27Kip1 in normal but not in transformed mammary epithelial cells. J. Cell. Physiol. 1999, 180, 245-254. [CrossRef] 
60. Killilea, D.W.; Ames, B.N. Magnesium deficiency accelerates cellular senescence in cultured human fibroblasts. Proc. Natl. Acad. Sci. USA 2008, 105, 5768-5773. [CrossRef]

61. Killilea, D.W.; Maier, J.A. A connection between magnesium deficiency and aging: New insights from cellular studies. Magnes. Res. 2008, 21, 77-82.

62. Rowe, W.J. Correcting magnesium deficiencies may prolong life. Clin. Interv. Aging 2012, 7, 51-54. [CrossRef] [PubMed]

63. Dominguez, L.; Veronese, N.; Barbagallo, M. Magnesium and Hypertension in Old Age. Nutrients 2020, 13, 139. [CrossRef] [PubMed]

64. Kobayashi, J. On geographical relationship between the chemical nature of river water and death rate from apoplexy. Ber. Ohara Inst. 1957, 11, 12-21.

65. Schroeder, H.A. Municipal drinking water and cardiovascular death rates. JAMA 1966, 195, 81-85. [CrossRef]

66. Altura, B.M.; Altura, B.T. Magnesium ions and contraction of vascular smooth muscles: Relationship to some vascular diseases. Fed. Proc. 1981, 40, 2672-2679.

67. Altura, B.M.; Altura, B.T.; Gebrewold, A.; Ising, H.; Gunther, T. Magnesium deficiency and hypertension: Correlation between magnesium-deficient diets and microcirculatory changes in situ. Science 1984, 223, 1315-1317. [CrossRef]

68. Turlapaty, P.D.; Altura, B.M. Magnesium deficiency produces spasms of coronary arteries: Relationship to etiology of sudden death ischemic heart disease. Science 1980, 208, 198-200. [CrossRef]

69. Iseri, L.T.; French, J.H. Magnesium: Nature's physiologic calcium blocker. Am. Heart J. 1984, 108, 188-193. [CrossRef]

70. Agus, Z.S.; Kelepouris, E.; Dukes, I.; Morad, M. Cytosolic magnesium modulates calcium channel activity in mammalian ventricular cells. Am. J. Physiol. 1989, 256 Pt 1, C452-C455. [CrossRef]

71. Grober, U.; Schmidt, J.; Kisters, K. Magnesium in Prevention and Therapy. Nutrients 2015, 7, 8199-8226. [CrossRef]

72. Maier, J.A.; Bernardini, D.; Rayssiguier, Y.; Mazur, A. High concentrations of magnesium modulate vascular endothelial cell behaviour in vitro. Biochim. Biophys. Acta 2004, 1689, 6-12. [CrossRef] [PubMed]

73. Barbagallo, M.; Dominguez, L.J.; Galioto, A.; Pineo, A.; Belvedere, M. Oral magnesium supplementation improves vascular function in elderly diabetic patients. Magnes. Res. 2010, 23, 131-137. [PubMed]

74. Altura, B.M.; Altura, B.T. Cardiovascular risk factors and magnesium: Relationships to atherosclerosis, ischemic heart disease and hypertension. Magnes. Trace Elem. 1991, 10, 182-192. [PubMed]

75. Joffres, M.R.; Reed, D.M.; Yano, K. Relationship of magnesium intake and other dietary factors to blood pressure: The Honolulu heart study. Am. J. Clin. Nutr. 1987, 45, 469-475. [CrossRef]

76. Petersen, B.; Schroll, M.; Christiansen, C.; Transbol, I. Serum and erythrocyte magnesium in normal elderly danish people. Relationship to blood pressure and serum lipids. Acta Med. Scand. 1977, 201, 31-34. [CrossRef]

77. Resnick, L.M.; Gupta, R.K.; Laragh, J.H. Intracellular free magnesium in erythrocytes of essential hypertension: Relation to blood pressure and serum divalent cations. Proc. Natl. Acad. Sci. USA 1984, 81, 6511-6515. [CrossRef]

78. Barbagallo, M.; Resnick, L.M.; Sosa, R.E.; Corbett, M.L.; Laragh, J.H. Renal divalent cation excretion in secondary hypertension. Clin. Sci. 1992, 83, 561-565. [CrossRef]

79. Resnick, L.M.; Gupta, R.K.; DiFabio, B.; Barbagallo, M.; Mann, S.; Marion, R.; Laragh, J.H. Intracellular ionic consequences of dietary salt loading in essential hypertension. Relation to blood pressure and effects of calcium channel blockade. J. Clin. Investig. 1994, 94, 1269-1276. [CrossRef]

80. Blackfan, K.; Hamilton, B. Uremia in acute glomerular nephritis: The cause and treatment in children. Med. Surg. J. 1925, 193, 617-628.

81. Chien, P.F.; Khan, K.S.; Arnott, N. Magnesium sulphate in the treatment of eclampsia and pre-eclampsia: An overview of the evidence from randomised trials. Br. J. Obstet. Gynaecol. 1996, 103, 1085-1091. [CrossRef]

82. Winkler, A.W.; Smith, P.K.; Hoff, H.E. Intravenous Magnesium Sulfate in the Treatment of Nephritic Convulsions in Adults. J. Clin. Investig. 1942, 21, 207-216. [CrossRef] [PubMed]

83. Dickinson, H.O.; Nicolson, D.J.; Campbell, F.; Cook, J.V.; Beyer, F.R.; Ford, G.A.; Mason, J. Magnesium supplementation for the management of essential hypertension in adults. Cochrane Database Syst. Rev. 2006, 3, CD004640.

84. Kass, L.; Weekes, J.; Carpenter, L. Effect of magnesium supplementation on blood pressure: A meta-analysis. Eur. J. Clin. Nutr. 2012, 66, 411-418. [CrossRef] [PubMed]

85. Dibaba, D.T.; Xun, P.; Song, Y.; Rosanoff, A.; Shechter, M.; He, K. The effect of magnesium supplementation on blood pressure in individuals with insulin resistance, prediabetes, or noncommunicable chronic diseases: A meta-analysis of randomized controlled trials. Am. J. Clin. Nutr. 2017, 106, 921-929. [CrossRef] [PubMed]

86. Veronese, N.; Demurtas, J.; Pesolillo, G.; Celotto, S.; Barnini, T.; Calusi, G.; Caruso, M.G.; Notarnicola, M.; Reddavide, R.; Stubbs, B.; et al. Magnesium and health outcomes: An umbrella review of systematic reviews and meta-analyses of observational and intervention studies. Eur. J. Nutr. 2020, 59, 263-272. [CrossRef]

87. Rayssiguier, Y. Role of magnesium and potassium in the pathogenesis of arteriosclerosis. Magnesium 1984, 3, 226-238. [PubMed]

88. Randell, E.W.; Mathews, M.; Gadag, V.; Zhang, H.; Sun, G. Relationship between serum magnesium values, lipids and anthropometric risk factors. Atherosclerosis 2008, 196, 413-419. [CrossRef]

89. Corsonello, A.; Perticone, F.; Ientile, R.; Barbagallo, M.; Corica, F. Serum magnesium and lipids: More clarity is needed. Atherosclerosis 2007, 192, 233-234. [CrossRef] 
90. Rosanoff, A.; Seelig, M.S. Comparison of mechanism and functional effects of magnesium and statin pharmaceuticals. J. Am. Coll. Nutr. 2004, 23, 501S-505S. [CrossRef]

91. DiCarlo, L.A., Jr.; Morady, F.; de Buitleir, M.; Krol, R.B.; Schurig, L.; Annesley, T.M. Effects of magnesium sulfate on cardiac conduction and refractoriness in humans. J. Am. Coll. Cardiol. 1986, 7, 1356-1362. [CrossRef]

92. McLean, R.M. Magnesium and its therapeutic uses: A review. Am. J. Med. 1994, 96, 63-76. [CrossRef]

93. Singh, R.B.; Manmohan, M.D.; Dube, K.P.; Singh, V.P. Serum magnesium concentrations in atrial fibrillation. Acta Cardiol. 1976, 31, 221-226. [PubMed]

94. Khan, A.M.; Lubitz, S.A.; Sullivan, L.M.; Sun, J.X.; Levy, D.; Vasan, R.S.; Magnani, J.W.; Ellinor, P.T.; Benjamin, E.J.; Wang, T.J. Low serum magnesium and the development of atrial fibrillation in the community: The Framingham Heart Study. Circulation 2013, 127, 33-38. [CrossRef] [PubMed]

95. Nielsen, F.H.; Milne, D.B.; Klevay, L.M.; Gallagher, S.; Johnson, L. Dietary magnesium deficiency induces heart rhythm changes, impairs glucose tolerance, and decreases serum cholesterol in post menopausal women. J. Am. Coll. Nutr. 2007, 26, 121-132. [CrossRef] [PubMed]

96. Onalan, O.; Crystal, E.; Daoulah, A.; Lau, C.; Crystal, A.; Lashevsky, I. Meta-analysis of magnesium therapy for the acute management of rapid atrial fibrillation. Am. J. Cardiol. 2007, 99, 1726-1732. [CrossRef]

97. Tzivoni, D.; Banai, S.; Schuger, C.; Benhorin, J.; Keren, A.; Gottlieb, S.; Stern, S. Treatment of torsade de pointes with magnesium sulfate. Circulation 1988, 77, 392-397. [CrossRef]

98. Gupta, A.; Lawrence, A.T.; Krishnan, K.; Kavinsky, C.J.; Trohman, R.G. Current concepts in the mechanisms and management of drug-induced QT prolongation and torsade de pointes. Am. Heart J. 2007, 153, 891-899. [CrossRef]

99. Chiuve, S.E.; Sun, Q.; Curhan, G.C.; Taylor, E.N.; Spiegelman, D.; Willett, W.C.; Manson, J.E.; Rexrode, K.M.; Albert, C.M. Dietary and plasma magnesium and risk of coronary heart disease among women. J. Am. Heart Assoc. 2013, 2, e000114. [CrossRef]

100. Stepura, O.B.; Martynow, A.I. Magnesium orotate in severe congestive heart failure (MACH). Int. J. Cardiol. 2009, 134, 145-147. [CrossRef]

101. Del Gobbo, L.C.; Imamura, F.; Wu, J.H.; de Oliveira Otto, M.C.; Chiuve, S.E.; Mozaffarian, D. Circulating and dietary magnesium and risk of cardiovascular disease: A systematic review and meta-analysis of prospective studies. Am. J. Clin. Nutr. 2013, 98, 160-173. [CrossRef]

102. Adebamowo, S.N.; Spiegelman, D.; Willett, W.C.; Rexrode, K.M. Association between intakes of magnesium, potassium, and calcium and risk of stroke: 2 cohorts of US women and updated meta-analyses. Am. J. Clin. Nutr. 2015, 101, 1269-1277. [CrossRef] [PubMed]

103. Drew, B.J.; Ackerman, M.J.; Funk, M.; Gibler, W.B.; Kligfield, P.; Menon, V.; Philippides, G.J.; Roden, D.M.; Zareba, W. Prevention of torsade de pointes in hospital settings: A scientific statement from the American Heart Association and the American College of Cardiology Foundation. Circulation 2010, 121, 1047-1060. [CrossRef] [PubMed]

104. Barbagallo, M.; Dominguez, L.J. Magnesium and type 2 diabetes. World J. Diabetes 2015, 6, 1152-1157. [CrossRef]

105. Mather, H.M.; Levin, G.E. Magnesium status in diabetes. Lancet 1979, 1, 924. [CrossRef]

106. Schnack, C.; Bauer, I.; Pregant, P.; Hopmeier, P.; Schernthaner, G. Hypomagnesaemia in type 2 (non-insulin-dependent) diabetes mellitus is not corrected by improvement of long-term metabolic control. Diabetologia 1992, 35, 77-79. [CrossRef] [PubMed]

107. Resnick, L.M.; Altura, B.T.; Gupta, R.K.; Laragh, J.H.; Alderman, M.H.; Altura, B.M. Intracellular and extracellular magnesium depletion in type 2 (non-insulin-dependent) diabetes mellitus. Diabetologia 1993, 36, 767-770. [CrossRef] [PubMed]

108. Barbagallo, M.; Di Bella, G.; Brucato, V.; D’Angelo, D.; Damiani, P.; Monteverde, A.; Belvedere, M.; Dominguez, L.J. Serum ionized magnesium in diabetic older persons. Metabolism 2014, 63, 502-509. [CrossRef]

109. Walti, M.K.; Zimmermann, M.B.; Walczyk, T.; Spinas, G.A.; Hurrell, R.F. Measurement of magnesium absorption and retention in type 2 diabetic patients with the use of stable isotopes. Am. J. Clin. Nutr. 2003, 78, 448-453. [CrossRef]

110. McNair, P.; Christensen, M.S.; Christiansen, C.; Madsbad, S.; Transbol, I. Renal hypomagnesaemia in human diabetes mellitus: Its relation to glucose homeostasis. Eur. J. Clin. Investig. 1982, 12, 81-85. [CrossRef]

111. Djurhuus, M.S.; Skott, P.; Hother-Nielson, O.; Klitgaard, N.A.; Beck-Nielsen, H. Insulin increases renal magnesium excretion: A possible cause of magnesium depletion in hyperinsulinaemic states. Diabet. Med. 1995, 12, 664-669. [CrossRef]

112. Rodriguez-Moran, M.; Simental Mendia, L.E.; Zambrano Galvan, G.; Guerrero-Romero, F. The role of magnesium in type 2 diabetes: A brief based-clinical review. Magnes. Res. 2011, 24, 156-162. [CrossRef] [PubMed]

113. Von Ehrlich, B.; Barbagallo, M.; Classen, H.G.; Guerrero-Romero, F.; Mooren, F.C.; Rodriguez-Moran, M.; Vierling, W.; Vormann, J.; Kisters, K. The significance of magnesium in insulin resistance, metabolic syndrome and diabetes-Recommendations of the association of magnesium research. V. I die bedeutung von magnesium für insulinresistenz, metabolisches sindrom un diabetes mellitus-Empfehlungen der gesellschaft für magnesium forschung e.V. Diabetol. Stoffwechs. 2014, 9, 96-100.

114. Veronese, N.; Watutantrige-Fernando, S.; Luchini, C.; Solmi, M.; Sartore, G.; Sergi, G.; Manzato, E.; Barbagallo, M.; Maggi, S.; Stubbs, B. Effect of magnesium supplementation on glucose metabolism in people with or at risk of diabetes: A systematic review and meta-analysis of double-blind randomized controlled trials. Eur. J. Clin. Nutr. 2016, 70, 1354-1359. [CrossRef] [PubMed]

115. Lopez-Ridaura, R.; Willett, W.C.; Rimm, E.B.; Liu, S.; Stampfer, M.J.; Manson, J.E.; Hu, F.B. Magnesium intake and risk of type 2 diabetes in men and women. Diabetes Care 2004, 27, 134-140. [CrossRef]

116. Song, Y.; Manson, J.E.; Buring, J.E.; Liu, S. Dietary magnesium intake in relation to plasma insulin levels and risk of type 2 diabetes in women. Diabetes Care 2004, 27, 59-65. [CrossRef] 
117. He, K.; Liu, K.; Daviglus, M.L.; Morris, S.J.; Loria, C.M.; Van Horn, L.; Jacobs, D.R., Jr.; Savage, P.J. Magnesium intake and incidence of metabolic syndrome among young adults. Circulation 2006, 113, 1675-1682. [CrossRef]

118. Matsunobu, S.; Terashima, Y.; Senshu, T.; Sano, H.; Itoh, H. Insulin secretion and glucose uptake in hypomagnesemic sheep fed a low magnesium, high potassium diet. J. Nutr. Biochem. 1990, 1, 167-171. [CrossRef]

119. Balon, T.W.; Gu, J.L.; Tokuyama, Y.; Jasman, A.P.; Nadler, J.L. Magnesium supplementation reduces development of diabetes in a rat model of spontaneous NIDDM. Am. J. Physiol. 1995, 269 Pt 1, E745-E752. [CrossRef]

120. Fung, T.T.; Manson, J.E.; Solomon, C.G.; Liu, S.; Willett, W.C.; Hu, F.B. The association between magnesium intake and fasting insulin concentration in healthy middle-aged women. J. Am. Coll. Nutr. 2003, 22, 533-538. [CrossRef]

121. Humphries, S.; Kushner, H.; Falkner, B. Low dietary magnesium is associated with insulin resistance in a sample of young, nondiabetic Black Americans. Am. J. Hypertens. 1999, 12 Pt 1, 747-756. [CrossRef]

122. Haury, V.G. Blood serum magnesium in bronchial asthma and its treatment by the administration of magnesium sulfate. J. Lab. Clin. Med. 1940, 26, 340-344.

123. Okayama, H.; Aikawa, T.; Okayama, M.; Sasaki, H.; Mue, S.; Takishima, T. Bronchodilating effect of intravenous magnesium sulfate in bronchial asthma. JAMA 1987, 257, 1076-1078. [CrossRef] [PubMed]

124. Bloch, H.; Silverman, R.; Mancherje, N.; Grant, S.; Jagminas, L.; Scharf, S.M. Intravenous magnesium sulfate as an adjunct in the treatment of acute asthma. Chest 1995, 107, 1576-1581. [CrossRef] [PubMed]

125. Tiffany, B.R.; Berk, W.A.; Todd, I.K.; White, S.R. Magnesium bolus or infusion fails to improve expiratory flow in acute asthma exacerbations. Chest 1993, 104, 831-834. [CrossRef] [PubMed]

126. Bernstein, W.K.; Khastgir, T.; Khastgir, A.; Hernandez, E.; Miller, J.; Schonfeld, S.A.; Nissim, J.E.; Chernow, B. Lack of effectiveness of magnesium in chronic stable asthma. A prospective, randomized, double-blind, placebo-controlled, crossover trial in normal subjects and in patients with chronic stable asthma. Arch. Intern. Med. 1995, 155, 271-276. [CrossRef] [PubMed]

127. Skorodin, M.S.; Freebeck, P.C.; Yetter, B.; Nelson, J.E.; Van de Graaff, W.B.; Walsh, J.M. Magnesium sulfate potentiates several cardiovascular and metabolic actions of terbutaline. Chest 1994, 105, 701-705. [CrossRef]

128. Rolla, G.; Bucca, C.; Brussino, L.; Colagrande, P. Effect of intravenous magnesium infusion on salbutamol-induced bronchodilatation in patients with asthma. Magnes. Res. 1994, 7, 129-133.

129. Chyrek-Borowska, S.; Obrzut, D.; Hofman, J. The relation between magnesium, blood histamine level and eosinophilia in the acute stage of the allergic reactions in humans. Arch. Immunol. Ther. Exp. 1978, 26, 709-712.

130. Kemp, P.A.; Gardiner, S.M.; March, J.E.; Bennett, T.; Rubin, P.C. Effects of NG-nitro-L-arginine methyl ester on regional haemodynamic responses to MgSO4 in conscious rats. Br. J. Pharmacol. 1994, 111, 325-331. [CrossRef]

131. Nadler, J.L.; Goodson, S.; Rude, R.K. Evidence that prostacyclin mediates the vascular action of magnesium in humans. Hypertension 1987, 9, 379-383. [CrossRef]

132. Britton, J.; Pavord, I.; Richards, K.; Wisniewski, A.; Knox, A.; Lewis, S.; Tattersfield, A.; Weiss, S. Dietary magnesium, lung function, wheezing, and airway hyperreactivity in a random adult population sample. Lancet 1994, 344, 357-362. [CrossRef]

133. Falkner, D.; Glauser, J.; Allen, M. Serum magnesium levels in asthmatic patients during acute exacerbations of asthma. Am. J. Emerg. Med. 1992, 10, 1-3. [CrossRef]

134. Gustafson, T.; Boman, K.; Rosenhall, L.; Sandstrom, T.; Wester, P.O. Skeletal muscle magnesium and potassium in asthmatics treated with oral beta 2-agonists. Eur. Respir. J. 1996, 9, 237-240. [CrossRef] [PubMed]

135. Dominguez, L.J.; Barbagallo, M.; Di Lorenzo, G.; Drago, A.; Scola, S.; Morici, G.; Caruso, C. Bronchial reactivity and intracellular magnesium: A possible mechanism for the bronchodilating effects of magnesium in asthma. Clin. Sci. 1998, 95, 137-142. [CrossRef]

136. Seelig, M.S. Consequences of magnesium deficiency on the enhancement of stress reactions; preventive and therapeutic implications (a review). J. Am. Coll. Nutr. 1994, 13, 429-446. [CrossRef]

137. Durlach, J.; Bac, P.; Bara, M.; Guiet-Bara, A. Physiopathology of symptomatic and latent forms of central nervous hyperexcitability due to magnesium deficiency: A current general scheme. Magnes. Res. 2000, 13, 293-302. [PubMed]

138. Botturi, A.; Ciappolino, V.; Delvecchio, G.; Boscutti, A.; Viscardi, B.; Brambilla, P. The Role and the Effect of Magnesium in Mental Disorders: A Systematic Review. Nutrients 2020, 12, 1661. [CrossRef]

139. Noah, L.; Pickering, G.; Mazur, A.; Dubray, C.; Hitier, S.; Duale, C.; Pouteau, E. Impact of magnesium supplementation, in combination with vitamin B6, on stress and magnesium status: Secondary data from a randomized controlled trial. Magnes. Res. 2020, 33, 45-57. [CrossRef]

140. Goto, Y.; Nakamura, M.; Abe, S.; Kato, M.; Fukui, M. Physiological correlates of abnormal behaviors in magnesium-deficient rats. Epilepsy Res. 1993, 15, 81-89. [CrossRef]

141. Galland, L. Magnesium, stress and neuropsychiatric disorders. Magnes. Trace Elem. 1991, 10, $287-301$.

142. Decollogne, S.; Tomas, A.; Lecerf, C.; Adamowicz, E.; Seman, M. NMDA receptor complex blockade by oral administration of magnesium: Comparison with MK-801. Pharmacol. Biochem. Behav. 1997, 58, 261-268. [CrossRef]

143. Eby, G.A., III; Eby, K.L. Magnesium for treatment-resistant depression: A review and hypothesis. Med. Hypotheses 2010, 74, 649-660. [CrossRef] [PubMed]

144. Derom, M.L.; Sayon-Orea, C.; Martinez-Ortega, J.M.; Martinez-Gonzalez, M.A. Magnesium and depression: A systematic review. Nutr. Neurosci. 2013, 16, 191-206. [CrossRef] [PubMed]

145. Nechifor, M. Magnesium in major depression. Magnes. Res. 2009, 22, 163S-166S. [CrossRef] 
146. Abbasi, B.; Kimiagar, M.; Sadeghniiat, K.; Shirazi, M.M.; Hedayati, M.; Rashidkhani, B. The effect of magnesium supplementation on primary insomnia in elderly: A double-blind placebo-controlled clinical trial. J. Res. Med. Sci. 2012, 17, 1161-1169.

147. Glick, J.L. Dementias: The role of magnesium deficiency and an hypothesis concerning the pathogenesis of Alzheimer's disease. Med. Hypotheses 1990, 31, 211-225. [CrossRef]

148. Yamanaka, R.; Shindo, Y.; Oka, K. Magnesium Is a Key Player in Neuronal Maturation and Neuropathology. Int. J. Mol. Sci. 2019, 20, 3439. [CrossRef]

149. Vural, H.; Demirin, H.; Kara, Y.; Eren, I.; Delibas, N. Alterations of plasma magnesium, copper, zinc, iron and selenium concentrations and some related erythrocyte antioxidant enzyme activities in patients with Alzheimer's disease. J. Trace Elem. Med. Biol. 2010, 24, 169-173. [CrossRef]

150. Cilliler, A.E.; Ozturk, S.; Ozbakir, S. Serum magnesium level and clinical deterioration in Alzheimer's disease. Gerontology 2007, 53, 419-422. [CrossRef]

151. Andrasi, E.; Pali, N.; Molnar, Z.; Kosel, S. Brain aluminum, magnesium and phosphorus contents of control and Alzheimerdiseased patients. J. Alzheimers Dis. 2005, 7, 273-284. [CrossRef]

152. Barbagallo, M.; Belvedere, M.; Di Bella, G.; Dominguez, L.J. Altered ionized magnesium levels in mild-to-moderate Alzheimer's disease. Magnes. Res. 2011, 24, S115-S121. [CrossRef] [PubMed]

153. Toffa, D.H.; Magnerou, M.A.; Kassab, A.; Hassane Djibo, F.; Sow, A.D. Can magnesium reduce central neurodegeneration in Alzheimer's disease? Basic evidences and research needs. Neurochem. Int. 2019, 126, 195-202. [CrossRef] [PubMed]

154. Wang, P.; Yu, X.; Guan, P.P.; Guo, J.W.; Wang, Y.; Zhang, Y.; Zhao, H.; Wang, Z.Y. Magnesium ion influx reduces neuroinflammation in Abeta precursor protein/Presenilin 1 transgenic mice by suppressing the expression of interleukin-1beta. Cell. Mol. Immunol. 2017, 14, 451-464. [CrossRef] [PubMed]

155. Yu, X.; Guan, P.P.; Guo, J.W.; Wang, Y.; Cao, L.L.; Xu, G.B.; Konstantopoulos, K.; Wang, Z.Y.; Wang, P. By suppressing the expression of anterior pharynx-defective-1alpha and -1beta and inhibiting the aggregation of beta-amyloid protein, magnesium ions inhibit the cognitive decline of amyloid precursor protein/presenilin 1 transgenic mice. FASEB J. 2015, 29, 5044-5058. [CrossRef] [PubMed]

156. Slutsky, I.; Abumaria, N.; Wu, L.J.; Huang, C.; Zhang, L.; Li, B.; Zhao, X.; Govindarajan, A.; Zhao, M.G.; Zhuo, M.; et al. Enhancement of learning and memory by elevating brain magnesium. Neuron 2010, 65, 165-177. [CrossRef]

157. Xu, Z.P.; Li, L.; Bao, J.; Wang, Z.H.; Zeng, J.; Liu, E.J.; Li, X.G.; Huang, R.X.; Gao, D.; Li, M.Z.; et al. Magnesium protects cognitive functions and synaptic plasticity in streptozotocin-induced sporadic Alzheimer's model. PLoS ONE 2014, 9, e108645. [CrossRef]

158. Cherbuin, N.; Kumar, R.; Sachdev, P.S.; Anstey, K.J. Dietary Mineral Intake and Risk of Mild Cognitive Impairment: The PATH through Life Project. Front. Aging Neurosci. 2014, 6, 4. [CrossRef]

159. Ozawa, M.; Ninomiya, T.; Ohara, T.; Hirakawa, Y.; Doi, Y.; Hata, J.; Uchida, K.; Shirota, T.; Kitazono, T.; Kiyohara, Y. Self-reported dietary intake of potassium, calcium, and magnesium and risk of dementia in the Japanese: The Hisayama Study. J. Am. Geriatr. Soc. 2012, 60, 1515-1520. [CrossRef]

160. Liu, G.; Weinger, J.G.; Lu, Z.L.; Xue, F.; Sadeghpour, S. Efficacy and Safety of MMFS-01, a Synapse Density Enhancer, for Treating Cognitive Impairment in Older Adults: A Randomized, Double-Blind, Placebo-Controlled Trial. J. Alzheimers Dis. 2016, 49, 971-990. [CrossRef]

161. New, S.A.; Robins, S.P.; Campbell, M.K.; Martin, J.C.; Garton, M.J.; Bolton-Smith, C.; Grubb, D.A.; Lee, S.J.; Reid, D.M. Dietary influences on bone mass and bone metabolism: Further evidence of a positive link between fruit and vegetable consumption and bone health? Am. J. Clin. Nutr. 2000, 71, 142-151. [CrossRef]

162. Tucker, K.L. Vegetarian diets and bone status. Am. J. Clin. Nutr. 2014, 100 (Suppl. S1), 329S-335S. [CrossRef] [PubMed]

163. Ryder, K.M.; Shorr, R.I.; Bush, A.J.; Kritchevsky, S.B.; Harris, T.; Stone, K.; Cauley, J.; Tylavsky, F.A. Magnesium intake from food and supplements is associated with bone mineral density in healthy older white subjects. J. Am. Geriatr. Soc. 2005, 53, 1875-1880. [CrossRef] [PubMed]

164. Kenney, M.A.; McCoy, H.; Williams, L. Effects of magnesium deficiency on strength, mass, and composition of rat femur. Calcif. Tissue Int. 1994, 54, 44-49. [CrossRef] [PubMed]

165. Rude, R.K.; Kirchen, M.E.; Gruber, H.E.; Meyer, M.H.; Luck, J.S.; Crawford, D.L. Magnesium deficiency-induced osteoporosis in the rat: Uncoupling of bone formation and bone resorption. Magnes. Res. 1999, 12, 257-267. [PubMed]

166. Rude, R.K.; Gruber, H.E. Magnesium deficiency and osteoporosis: Animal and human observations. J. Nutr. Biochem. 2004, 15, 710-716. [CrossRef]

167. Medalle, R.; Waterhouse, C.; Hahn, T.J. Vitamin D resistance in magnesium deficiency. Am. J. Clin. Nutr. 1976, $29,854-858$. [CrossRef]

168. Aydin, H.; Deyneli, O.; Yavuz, D.; Gozu, H.; Mutlu, N.; Kaygusuz, I.; Akalin, S. Short-term oral magnesium supplementation suppresses bone turnover in postmenopausal osteoporotic women. Biol. Trace Elem. Res. 2010, 133, 136-143. [CrossRef]

169. Dimai, H.P.; Porta, S.; Wirnsberger, G.; Lindschinger, M.; Pamperl, I.; Dobnig, H.; Wilders-Truschnig, M.; Lau, K.H. Daily oral magnesium supplementation suppresses bone turnover in young adult males. J. Clin. Endocrinol. Metab. 1998, 83, $2742-2748$. [CrossRef]

170. Veronese, N.; Stubbs, B.; Solmi, M.; Noale, M.; Vaona, A.; Demurtas, J.; Maggi, S. Dietary magnesium intake and fracture risk: Data from a large prospective study. Br. J. Nutr. 2017, 117, 1570-1576. [CrossRef] 
171. Sendur, O.F.; Tastaban, E.; Turan, Y.; Ulman, C. The relationship between serum trace element levels and clinical parameters in patients with fibromyalgia. Rheumatol. Int. 2008, 28, 1117-1121. [CrossRef]

172. Bagis, S.; Karabiber, M.; As, I.; Tamer, L.; Erdogan, C.; Atalay, A. Is magnesium citrate treatment effective on pain, clinical parameters and functional status in patients with fibromyalgia? Rheumatol. Int. 2013, 33, 167-172. [CrossRef] [PubMed]

173. Rock, E.; Astier, C.; Lab, C.; Vignon, X.; Gueux, E.; Motta, C.; Rayssiguier, Y. Dietary magnesium deficiency in rats enhances free radical production in skeletal muscle. J. Nutr. 1995, 125, 1205-1210. [PubMed]

174. Dominguez, L.J.; Barbagallo, M.; Lauretani, F.; Bandinelli, S.; Bos, A.; Corsi, A.M.; Simonsick, E.M.; Ferrucci, L. Magnesium and muscle performance in older persons: The InCHIANTI study. Am. J. Clin. Nutr. 2006, 84, 419-426. [CrossRef] [PubMed]

175. Brilla, L.R.; Haley, T.F. Effect of magnesium supplementation on strength training in humans. J. Am. Coll. Nutr. 1992, 11, 326-329. [CrossRef] [PubMed]

176. Veronese, N.; Berton, L.; Carraro, S.; Bolzetta, F.; De Rui, M.; Perissinotto, E.; Toffanello, E.D.; Bano, G.; Pizzato, S.; Miotto, F.; et al. Effect of oral magnesium supplementation on physical performance in healthy elderly women involved in a weekly exercise program: A randomized controlled trial. Am. J. Clin. Nutr. 2014, 100, 974-981. [CrossRef] [PubMed]

177. Leidi, M.; Wolf, F.; Maier, J.A.M. Magnesium and cancer: More questions than answers. In Magnesium in the Central Nervous System; Vink, R., Nechifor, M., Eds.; University of Adelaide Press: Adelaide, Australia, 2011.

178. Feng, J.F.; Lu, L.; Zeng, P.; Yang, Y.H.; Luo, J.; Yang, Y.W.; Wang, D. Serum total oxidant/antioxidant status and trace element levels in breast cancer patients. Int. J. Clin. Oncol. 2012, 17, 575-583. [CrossRef]

179. Bezerra, D.L.C.; Mendes, P.M.V.; Melo, S.R.S.; Dos Santos, L.R.; Santos, R.O.; Vieira, S.C.; Henriques, G.S.; Freitas, B.; Marreiro, D.D.N. Hypomagnesemia and Its Relationship with Oxidative Stress Markers in Women with Breast Cancer. Biol. Trace Elem. Res. 2021, 1-9.

180. Patiroglu, T.; Sahin, G.; Kontas, O.; Uzum, K.; Saraymen, R. Protective effect of magnesium supplementation on experimental 3-methyl cholanthrene-induced fibrosarcoma and changes in tissue magnesium distribution during carcinogenesis in rats. Biol. Trace Elem. Res. 1997, 56, 179-185. [CrossRef]

181. Kasprzak, K.S.; Diwan, B.A.; Rice, J.M. Iron accelerates while magnesium inhibits nickel-induced carcinogenesis in the rat kidney. Toxicology 1994, 90, 129-140. [CrossRef]

182. Hanano, T.; Hara, Y.; Shi, J.; Morita, H.; Umebayashi, C.; Mori, E.; Sumimoto, H.; Ito, Y.; Mori, Y.; Inoue, R. Involvement of TRPM7 in cell growth as a spontaneously activated $\mathrm{Ca}^{2+}$ entry pathway in human retinoblastoma cells. J. Pharmacol. Sci. 2004, 95, 403-419. [CrossRef]

183. Wark, P.A.; Lau, R.; Norat, T.; Kampman, E. Magnesium intake and colorectal tumor risk: A case-control study and meta-analysis. Am. J. Clin. Nutr. 2012, 96, 622-631. [CrossRef] [PubMed]

184. Sahmoun, A.E.; Singh, B.B. Does a higher ratio of serum calcium to magnesium increase the risk for postmenopausal breast cancer? Med. Hypotheses 2010, 75, 315-318. [CrossRef] [PubMed]

185. Sun, P.; Zhu, X.; Shrubsole, M.J.; Ness, R.M.; Hibler, E.A.; Cai, Q.; Long, J.; Chen, Z.; Li, G.; Hou, L.; et al. Genetic variation in SLC7A2 interacts with calcium and magnesium intakes in modulating the risk of colorectal polyps. J. Nutr. Biochem. 2017, 47, 35-40. [CrossRef] [PubMed]

186. Shah, S.C.; Zhu, X.; Dai, Q.; Peek, R.M.; Shrubsole, M.J. Magnesium intake is associated with a reduced risk of incident liver cancer, based on an analysis of the NIH-American Association of Retired Persons (NIH-AARP) Diet and Health Study prospective cohort. Am. J. Clin. Nutr. 2020, nqaa326. [CrossRef] [PubMed] 